\title{
The Impact of Single and Multiple Mergers and Acquisitions on Shareholders' Wealth of UK Bidder Firms
}

\author{
George Giannopoulos ${ }^{1}$, Ehsan Khansalar $^{1} \&$ Patel Neel $^{1}$ \\ ${ }^{1}$ Kingston Business School, Kingston University, London, UK \\ Correspondence: Ehsan Khansalar, Kingston Business School, Kingston University, London, UK. E-mail: \\ E.Khansalar@kingston.ac.uk
}

Received: January 16, 2017

Accepted: February 9, 2017

Online Published: February 20, 2017

doi:10.5539/ijef.v9n3p141

URL: https://doi.org/10.5539/ijef.v9n3p141

\begin{abstract}
This study investigates the impact of takeover announcements on UK acquirer shareholders' wealth during the period 2002-2006. More specifically, it is investigated whether the impact of single acquirers on shareholders' wealth is significantly different from the impact of multiple acquirers. Findings suggest that acquirer shareholders experience positive abnormal returns during the announcement period. Moreover, the results indicate single acquirers consistently outperform multiple acquirers when testing for deal characteristics such as: payment method (cash or equity), target status (public or private), target location (domestic or cross-border) and industry relatedness (specification or diversification). Performance declines with sequential acquisitions due to merger programme announcement hypothesis. Successful first time acquirers suffer from hubris whilst unsuccessful first time acquirers learn from their experiences suggested by the organisation learning hypothesis but go on to suffer from hubris. Acquisitions of private firms yield significant abnormal returns whereas public acquisitions reduce the value of UK acquirers. The effect of cash and equity, domestic and foreign, related and unrelated takeovers are inconclusive for the short-term windows investigated by this study.
\end{abstract}

Keywords: mergers and acquisitions, takeover announcements, shareholders' wealth

\section{Introduction}

\subsection{Background}

The value of mergers and acquisitions (M\&A) deals has grown steadily since the early 1980s with the exception of the global financial crisis between 2008 and 2010 which saw a sharp decrease in both value and number of transactions (Thomson-One-Banker, 2011). The majority of the capital spent on M\&A activities from 1990s onwards have emerged from multiple acquirers (Ismail, 2008). However, Noe (2006) suggests that on average sixty to eighty per-cent of all M\&As are considered failureswhen a review is conducted on a merger's announcement stock market effects on shareholders' value. This raises some interesting questions worth investigating with an apparent high failure rate: (1) why do firms carry out multiple takeovers? (2) What effect, if any, do multiple acquisitions have on the bidder firms' shareholders return when compared to single acquisitions?' The investigation of these issues forms a major part of this study.

Extensive research on market performance to $M \& A$ announcements has been carried out in attempt to deduce whether M\&As have a positive or adverse effect on shareholders' wealth. Brown and Warner (1980) were amongst the first who illustrated in detail how to measure the impact of M\&As during the announcement period using an event study methodology. Firth $(1976,1979,1980)$ carried out some of the earliest studies of this event study using UK data which has been expanded by various other studies in the 90s (Sudarsanam et al., 1996), and more recently by Hodgkinson and Partkington (2008) and Gortan et al. (2009).

Whilst most studies agree M\&As create value for target firms, the results for bidding firms regarding abnormal returns are generallyinconclusive. Some studies report significant negative abnormal returns (Firth, 1980; Sudarsanam et al., 1996) whilst others point towards positive abnormal returns (Berkovitch \& Narayanan, 1993). Other studies shedlight on the impact of various takeover circumstances on abnormal returns. Moeller et al. $(2003,2004)$ found acquisitions of private firms yielded positive abnormal returns whilst public firms yielded negative abnormal returns, and smaller acquirers consistently out-performed larger acquirers.

Few studies focus on multiple acquisitions and the findings are inconclusive. Rovit and Lemire (2003) have 
indicated that multiple acquisitions increase shareholder value and attribute this to management benefiting from the organisational learning hypothesis. In contrast Fuller et al. (2002) and Billet and Qian (2005) have indicated multiple acquisitions, on some occasions, have resulted in value destruction for bidder shareholders.

There are numerous reasons outlined in various studies which attempt to deduce why companies continually seek to engage in M\&A activities. Some consider maintaining competitive advantage in existing markets or entering new markets and expanding business portfolios through synergetic gains. There are also a number of theories such as the agency theory, which suggests that multiple takeovers are as a result of managerial decisions that create little or no value to the firm. However, studies directly exploring the difference between single and multiple acquirers' effect on shareholders wealth across the same data range is very limited. Ismail (2008) discovered, using US firms between 1980 and 2004, that single acquirers out performed multiple acquirers. This finding was confirmed when testing for robustness under various deal characteristics. In contrast, Conn et al. (2004) found little difference between the performance effects of single and multiple acquirers for UK firms between 1984 and 1998. They however found that multiple acquirers performance declined significantly with subsequent acquisitions.

\subsection{Aims and Objectives}

The aim of this study is to investigate acquirer shareholders wealth using a sample of M\&A UK firms for the five years between 2002 and 2006 by:

- Measuring shareholder returns in the bidding firms during the announcement period

- Examining whether on average, the impact to shareholder returns of acquisition made by multiple acquirers exceed that of single acquirers and testing for different deal characteristics: including location (domestic versus foreign), payment method (cash versus equity), target status (public versus private or subsidiary) and relatedness (related or unrelated).

- Measuring the impact of deal order number on acquirer shareholder returns for sequential acquisitions.

\subsection{Motivation}

The motivation for this research topic stems from the growing number of multiple mergers and acquisitions in recent years, particularly the topical debate on whether the increase in M\&A activity has increased or decreased shareholders wealth. Moreover, this studyis interested in understanding how M\&A activity levels affect shareholders' wealth and whether correlations can be drawn by looking at various parameters.

\subsection{Contribution}

The purpose of this dissertation is to add to the works of Ismail (2008) and Conn et al. (2004) in comparing the effects of single and multiple acquirers on shareholders wealth when testing for deal characteristics and investigating whether sequential acquisitions are successful these issues are investigated using UK data during the 2002-2006 sample period. Findings will be compared with similar studies by Ismail (2008) and Conn et al. (2004) as well as other relevant literature.

The rest of this study is structured as follows: Section 2 reviews the empirical work in the area of single and multiple acquirers. Section 3 outlines the methodology used in this study. Section 4 presents the results and critically analyses them. Section 5 summarises the main findings, explains this study's limitation and provides suggestions for further research.

\section{Literature Review}

There are two main approaches in the literature employed to measure the impact of M\&A. The first, common in finance literature, is the stock market valuation approach which presumes that the market is efficient. This implies that any changes in share prices for the bidder and target firms, after controlling for general movement in the market and systematic risk of the firm, represents the economic value of the acquisition and is commonly referred to as the market model (Fama et al., 1969). However, a truly efficient capital market may not exist in practice and can lead to misinterpreted finding. The second approach, common in industrial organisation literature, examines firms' performance via profitability by using accounting data (see Meeks, 1977; Healy et al. 1992, 1997; Dickerson et al., 1997). However, this approach has limitations when comparing firms that use different accounting procedures and/or creative accounting (Dickerson et al., 1997).

\subsection{General Effect of M\&A Deals}

It is widely accepted by most empirical studies that target firms experience significant increases in shareholder wealth (see Figure A1), however the effects on acquirer firms are scant at best. With synergy value-maximisation 
motives, it is reasonable to expect both entities to benefit from the merger activity, thus acquirer shareholders should see a positive return. Hubris motive though suggests the combined value of the firm is likely to decrease slightly during the takeover, with the targets experiencing gains and the acquirers absorbing the losses..

In an early study of UK M\&A activities between the period of 1955 and 1972, Frank et al. (1977) found a net gain for the combined companies with most gains accrued by the target and no significant losses to acquirers, indicating synergy as the potential motive, although the study was limited to the distillery industry. In contrast studies conducted by Firth $(1976,1979)$ found bidding firms experienced a fall in share price at announcement with sustained losses over the subsequent years. He further states that takeovers are initiated for reasons other than shareholder wealth maximisation, potentially managerial utility maximisation or hubris.

Firth (1980) supported his earlier findings with a larger sample between 1969-1975.He found the combined effect of the takeover was usually positive but acquirers on average experienced significant wealth loss for the first month after the announcement period. Sudarsanam et al. (1996) achieved similar results on average using a sample of 429 UK completed acquisitions between 1980 and 1990. Limmack (1991) found negligible abnormal returns for bidding firms during bid periods for completed bids but a significant loss for abandoned bids, an indicator of investors' discontent with the failure of the bid. Similarly, Higson and Elliott's (1998) study of successful acquisitions also found negligible abnormal returns for the bidding firm during the event window from the announcement date to the acquisition completion date, commonly referred to as the 'bidding period'. In contrast Archbold (2000) noted negative abnormal returns for acquirers during the bidding period. Moreover, Franks and Harris (1989) reported significant positive abnormal returns of $7.9 \%$ for bidder shareholders between the -4 and +1 months of the announcement period. However, this reduced sharply to just $1 \%$ when the event period was restricted to just the announcement month, suggesting less gains were attributed to the announcement.

Bidder returns have on average declined slightly over time as the premiums paid for target firms have increased (DePamphilis, 2009, p. 30). Conversely a more recent study by Hodgkinson and Partington (2008) finds long standing acquirer shareholders gained wealth, by securing their shares six months prior to takeover and held onto the share for twenty-four months after takeover completion. However Sudarsanam and Mahate (2003) sampled 519 UK listed acquirers from 1983 to 1995 and found acquirer shareholders experienced wealth loss over a longer event from announcement to three years post acquisition. They also found losses to acquirers were common for much smaller event windows, $(-1,+1)$ which is the three days surrounding the acquisition announcement.Also bidders earned abnormal returns between $-1.39 \%$ to $-1.47 \%$ (all significant) using various benchmarks. Antoniou et al. (2008) yielded similar results for the five day announcement event window $(-2,+2)$ generating $-1.4 \%$.

Having considered previous research on shareholders' abnormal returns, this study is concerned with the variation of findings for acquirers, thus the first hypothesis to be tested for UK bidding firms between 2002 and 2006 is as follows:

\section{H1 $1_{0}$ There are no wealth gains experienced by acquirer shareholders as a result of a takeover announcement.}

\subsection{Effect of Multiple M\&A Deals}

Malatesta and Thompson (1985) found acquisition announcements of active acquirers provided significant bidder returns, contradicting the popular belief that acquirers experience wealth loss. However, findings were limited to a sample of just thirty firms and were not compared with single acquirers. Additionally, Baker and Limmack (2001) find regular acquirers suffer no significant wealth losses, irrespective of the control model adopted, and consistently outperform single acquirers. Another argument, supported by diminishing merger programme announcement, and hubris hypotheses, suggests single acquirers will perform better than multiple acquirers. (Removed due to lack of source). Loderer and Martin (1990) examined short-run return of 5172 takeovers by 1538 unique acquirers between 1966 and 1984. They found first acquisitions lead to significant announcement effects, usually positive, whilst sequential acquisitions, confined to a series that started and ended with a two-year hiatus, followed a pattern of lower returns and ascribed this to the diminishing hypotheses. They put these findings down to the weaker revaluations of the acquiring firm that occurs from an announcement of subsequent acquisitions. Again, findings were not compared with single acquirers and it is feasible that multiple acquirers could still have on average achieved higher abnormal returns than single acquirers.

Unlike most papers which examine either single acquisitions or multiple acquisitions, or fail to separate the two entirely, Ismail (2008) compares both single and multiple acquirers. Based on 16,221 US takeovers, hefinds single acquirers outperform multiple acquirers.Acquiring firm shareholders earned $1.22 \%$ abnormal returns in 
the five days surrounding the announcement date with multiple acquirers outperforming single acquirers by $1.66 \%$. Various tests for robustness checks, such as hiatus period between acquisition, were imposed but single acquirers' performance consistently exceeded multiple acquirers.

In contrast, Conn et al. (2004) reported little difference when examining the relative performance effects of single and multiple acquirers $(0.88 \%$ and $0.48 \%$ respectively). However, their findings indicated a decline only occurred for acquirers whose first acquisitions were successful, and a positive effect for subsequent acquisitions for acquirers whose first acquisition was unsuccessful. These results are further supported by the hubris effect and diminishing hypothesis for successful first acquirers, and organisational learning hypothesis for unsuccessful first acquirers. Ismail (2008) reported a similar pattern, noting: 'Unsuccessful first time acquirers learn but successful first time bidders suffer from hubris behaviour in subsequent acquisitions.'

Moreover, Ismail (2008) reported a positive return up to the sixth deal but the seventh deal onwards had negligible gains or reporting losses. Rovit and Lemire (2003) examined the performance of 7475 takeovers between 1986 and 2001 by 724 large US firms. They discovered acquirers who had carried out more than 20 takeovers during this period outperformed firms that had only made up to four deals by a factor of 1.7. Asquith et al. (1983) found most bidding firms make multiple bids, with forty-five percent of the companies sampled making four or more bids. They concluded on average significantly positive abnormal returns remained constant for sequential acquisitions through to the fourth and fifth bids even for firms that had previously announced an acquisition program, dispelling the diminishing and merger programme announcement hypothesis. Instead, the findings are consistent with value-maximisation behaviour by management, suggesting synergy as the motive. On the other hand, Billet and Qian (2005) in their restricted study of frequent acquirers found a wealth loss, consistent with hubris hypothesis.

In summary, there is evidence suggesting that single acquirers outperform multiple acquirers. On the other hand the evidence supporting sequential acquisitions is less obvious, with some empirical research suggesting management gain from organisational learning hypothesis while others suggest management suffer from hubris. Therefore if hypothesis $\mathrm{H}_{0}$ is rejected then the following null hypotheses shall be investigated:

$H 2_{0}$ : $\quad$ There are no wealth gain disparities experienced between single and multiple acquirer shareholders as a result of a takeover announcement.

$H 3_{O a}$ : When considering multiple acquirers, performance of wealth gains is not affected by deal order number. And if $\mathrm{H}_{0_{0 \mathrm{a}}}$ is rejected then:

$H 3_{0 b}$ : There is no wealth increase/decrease for sequential acquisitions for successful/unsuccessful first time acquirers.

\subsection{Deal Characteristics}

The vast yet inconclusive findings of acquirer returns surrounding M\&A announcements have in recent years encouraged researchers to explore the extent of abnormal return sensitivity to the various bid characteristics. The type of characteristics perceived to have potential material impact and worth exploring include: method of payment (cash or shares); target type (private, public or subsidiary); location (domestic or foreign) and industry relatedness (related, unrelated). Ismail (2008) compared single and multiple acquirers' wealth gains and also tested the sensitivity of results for deal characteristics. He found some interesting results that would be further investigated by this study.

\subsubsection{Payment Method (Cash or Stock)}

In the process of financing a takeover, the bidding firm has a payment choice of either through an exchange of shares or cash, or a combination of the two. Cash payment is when the acquiring firm purchases the shares of the target firm shareholders, often at a premium. This method of payment would allow the target firm shareholders toobtain a stock option in the combined firm, diluting the proportion of ownership. Therefore, cash payment would be advantageous for the acquiring firm if their agenda is to maintain the same level of control over their existing organisation. Also, cash deals appeared to be the most popular choice of financing for both single and multiple acquirers at $71 \%$ and $61 \%$ respectively (See Figure A2) (Moved from data section). However, from the target shareholders' perspective, any cash payment would be subjected to capital gains tax so stock options wouldbe the preferred option (Arnold 2008).

Previous studies suggest cash takeover bids contribute to positive abnormal returns for acquirer shareholders and equity bids contribute to negative abnormal returns (see Walker, 2000; Moellet et al., 2004; Sudarsanam \& Mahate, 2006; Loughran \& Vijh, 2007). 
Chang (1998) examined bidder returns at the announcement of takeover proposals when the target firms were privately held. He found bidders experienced a positive abnormal return for stock deals and no abnormal return in cash offers. Chang (1998) further notes that the positive wealth effect is related to monitoring activities by private target shareholders. Chang and Mais (2000) investigated managerial motives behind takeovers of private firms. They found private firms generally have fewer shareholders with greater scrutiny and influence presenting a situation where stockholders are able to intervene in management's takeover decision, therefore any value-destruction takeovers are more likely to be prevented. Also, if the private target firm shareholders believed in the management of the acquirer firm then they are more likely to agree in obtaining stocks in the combined firm, sending a positive signal to the market.

Sudarsanam and Mahate (2003) explored the informational signalling effect of payment method, particularly when information asymmetry was present. If the management of the acquirer firm believes the target firm shareholders has private information regarding the value of the acquirer assets then it would likely be a stock payment. Conversely if the management believes, through private information, that the target firm is undervalued then the deal is likely to be a cash deal.

In a study of 16,221 takeovers in the US between 1985 and 2004, Ismail (2008) found half the deals were paid in cash, whilst only 3038 in stocks and 4485 were mixed deals. Through a dummy variable method, Ismail finds the significant gains difference between single and multiple acquirers for cash and equity method of payments. This leads to the fourth null hypothesis which is:

$H_{\text {Oa }}$ : Acquirer shareholder returns is not affected by method of payment, and;

H4 ${ }_{0 b}$ : Any difference in abnormal returns between shareholders of single and multiple acquirers is not affected by method of payment.

\subsubsection{Target Status}

Moeller et al. (2003) found bidder shareholders abnormal returns to be highly sensitive to target type, with significant gains when acquiring privately traded firms and losses when the target is a publicly listed firm. In a subsequent study, Moeller et al. (2004) also found large acquirers of publicly listed target firms experienced negative abnormal returns at announcement periods. A sub-study testing the sensitivity of the results, with regard to a cash or stock deal, concluded payment method had no influence on the findings.

Fuller et al. (2002) examined the effect of multiple (five or more) public, private, and/or subsidiary targets within a short time frame in the 1990s with US firms. They state that acquisition of private firms or subsidiaries yielded positive returns whilst public firms yielded losses. Fuller et al. (2002) suggest the results could be a reflection of the higher premiums required for a public takeover as opposed to a private takeover. In addition, tests for sensitivity to method payment found takeovers of private firms remained positive for both stock or cash deals whereas public target firms experienced wealth loss for stock deals and negligible returns for cash deals.

Billett and Qian (2005) examined the acquisition effect of firms that acquired two or more public firms within five years between the years of 1985-2002. Their results like that of Fuller et al. (2002) revealed acquirers of public firms (after their first acquisition) experienced on average negative wealth,.

When testing between single and multiple acquirers by deal characteristics, Ismail (2008) found single acquirers performed better than multiple acquirers with a difference in cumulative average abnormal returns of $1.22 \%$ for private firms, $2.08 \%$ for public and $1.85 \%$ for subsidiaries all at significant levels. Takeovers of private and subsidiary firms yielded positive abnormal returns whiletakeover of public firms led to wealth loss. Ismail (2008) suggests higher premiums as the probable reason for the negative abnormal returns with regard to public firms. Therefore, the following null hypothesis regarding target status shall be investigated:

$H 5_{0 a}: \quad$ Acquirer shareholder returns is not affected by target type, and;

H5 $5_{0 b}$ : Any difference in abnormal returns between shareholders of single and multiple acquirers is not affected by target type.

\subsubsection{Location (Foreign or Domestic)}

There has been a growing trend in cross-border takeovers since the fifth merger wave. By the year 2000, The UK activity in cross-border acquisitions accounted for $31 \%$ of the total value in the world, making the UK the largest acquiring country in the world (UNCTAD, 2000).

A major contributing factor for the growth in foreign takeovers stems from the fact that management seek to gain from operational synergies through the increase in economies of scope, diversification and entry to new markets. In addition Cakici et al. (1991) discuss the potential financial advantages in weak currency and favourable tax 
treatments. However, they go on to mention that target firm management are aware of these advantages and will therefore aim to achieve a greater price for the takeover than if the acquirer was domestic.

They also argue that "while a devalued dollar might enable the foreign buyer to acquire at a discount, the cash flows subsequent to the merger are correspondingly less valuable when converted back into the foreign currency at the current exchange rate. Thus, a low foreign exchange value does not justify high prices for target firms" (Cakici et al., 1991, p. 45).Their findings go on to support this theory as there is little difference in the abnormal returns between foreign and domestic acquirers, but a large variation between premiums paid by different countries.

Conn et al. (2003) examine the announcement and post-acquisition share returns of 4,000 acquisitions by U.K. public firms during 1984-1998. Overall, their results found domestic acquisitions result in higher announcement and long run returns than foreign acquisitions. Their results also suggest that the national cultural difference between the bidder and target countries has a significantly negative impact on long run returns.

In contrast, a recent study by Feito Ruiz and Menedez-Requejo (2009) of 469 (221 cross-border and 248 domestic) takeovers between 2002 and 2006 found acquirer shareholders experienced cumulative average abnormal returns of $1.38 \%$ in foreign target takeovers compared to just $0.64 \%$ for domestic takeovers for the three days surrounding the announcement period. This indicates operation and financial synergetic gains as the motives.

Ismail (2008) found domestic deals performed slightly better than cross-border deals but single acquirers outperformed multiple acquirers in both domestic and cross-border deals at $1.65 \%$ and $1.57 \%$ respectively. However, research regarding the impact of target location for acquirer shareholders is inconclusive and research comparing the success between multiple and single acquirer regarding location is greatly limited. Therefore, the sixth null hypothesis to be tested is:

$H 6_{0 a}: \quad$ Acquirer shareholder returns is not affected by target location, and;

H6 $6_{0 b}: \quad$ Any difference in abnormal returns between shareholders of single and multiple acquirers is not affected by target location.

\subsubsection{Industry Relatedness (Related or Unrelated)}

There are essentially two contrasting views regarding industry relatedness. The first suggests acquirers in a related industry takeover bid will experience higher abnormal returns from operational synergies as the acquiring firm already has the expertise and knowledge required in the industry (Sudarsanam et al., 1996). However, the second view suggests unrelated takeover bids are more successful as most of the synergies for related bids have already been realised and that diversification provides greater abnormal returns for acquirer shareholders.

Morck et al. (1990) conducted one of the earliest studies regarding industry relatedness with 326 US acquiring firms between 1975 and 1987 for long and short-run periods. Their findings revealed unrelated acquisitions performed better than related acquisitions but only significant between 1980 and 1987 at $6.97 \%$ for the three days surrounding the event. This period falls shortly after the fifth merger wave, a period renown for the high numbers of hostile diversification takeovers.

More recently, Walker (2000) study of 278 acquisitions by US firms between 1980 and 1996 revealed significant abnormal returns from related bids of $1.59 \%$ and unrelated acquisitions exhibited significant wealth losses of $-1.6 \%$. The study was also conducted over a small event window $(-2,+2)$. Whereas Sudarsanam et al. (1996), across a larger event window of $(-40,+40)$, found no significant effect of the relatedness for a sample of 429 UK listed firms between 1980 and 1990.

Ismail (2008) found unrelated takeovers accounted for approximately forty-percent of takeovers for both single and multiple acquirers (1018 of 2481 deals and 5292 of 13740 deals respectively) and yielded greater abnormal returns than related deals. The findings support the view that firms benefit from the synergies gained with a diversified portfolio. A further exploration found single acquirers outperformed multiple acquirers and on average had a greater difference in abnormal return for unrelated and related abnormal returns at $3.85 \%$ and $1.78 \%$ respectively, compared to multiple acquirer at $1.04 \%$ and $0.92 \%$ respectively (all statistically significant at $1 \%$ ). Ismail (2008) does not explicitly justify these differences but suggests that relative size, and valuation difference could explain the higher returns for single acquirers leading to the hypothesis which is: The following hypothesis shall then be tested:

$H 7_{o a}: \quad$ Acquirer shareholder returns is not affected by target relatedness, and;

H7 $7_{o b}$ : Any difference in abnormal returns between shareholders of single and multiple acquirers is not 


\section{affected by target relatedness.}

\section{Methodology and Data}

The choice of an event study method is deemed most appropriate for this study and an outline of the event study procedure is illustrated in accordance to Mackinglay (1997). Identification of event days, determining event windows and sample criteria are also provided. Furthermore, the benchmark models for expected returns are discussed (Brown \& Warner, 1980), followed by formulae of the expected, abnormal and cumulative abnormal returns

\subsection{Event Study Procedure}

Mackinglay (1997) discusses the importance of outlining the procedure of an event study so that there is a general flow of analysis which will provide the basis for the discussion. The initial task is to define an event of interest and the 'event window' by identifying the period over which the security price of the firms in question will be examined. Firms sampling must undergo a thorough selection criteria process, which includes data availability of securities and share prices. The next step is to collate the share price information within the event windows of the firms and calculate abnormal returns for the securities. Cumulative abnormal return calculations provide further analysis of the data. These findings will be tested against the hypothesis drawn from the literature review for analysis and concluding remarks.

\subsubsection{Identification of Event Days and Choice of Event Windows}

Mackinglay (1997) described an event period as capturing the share price at the event window (announcement day, time $t=0$ ). This would be in the context of share price leading to the announcement (estimation window) and share price subsequent to announcement (post-event window) as illustrated in Figure 1.

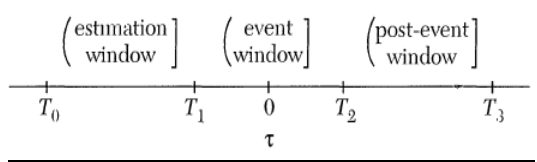

Figure 1. Event time line

Source: (Mackinglay, 1997, p. 20).

\section{Estimation Window}

Estimation window is utilised to 'predict' what would be the expected return of the security if the event did not occur and requires a benchmark model The event study methodology is built upon the assumption that the event impact is captured by abnormal return, thus estimation period should not overlap with the event window to ensure that there is no influence by the returns surrounding the event window. For this reason, this study will use an adjusted (Note 1) estimation window of -210 days to -21 days, in line with Ismail (2008).

\section{Event Window}

The event window can vary significantly depending on the objective of the analysis. Longer periods can be used to capture the wider effects of the announcement but the data is likely to suffer from 'noise' making it less accurate (Weston et al., 2004). This study focuses on the abnormal returns surrounding the event and will therefore be in line with other research of small windows: $-1,+1$ (Moeller et al. 2004) and $-2,+2$ (Fuller et. al. 2002). Prior knowledge of an acquisition can have predetermined effects on shares beyond the immediate approach of the deal, thus some studies are required to utilise a larger estimation window such as Cakici et al. (1991) $-10,+1$.

\section{Post -Event Window}

The post event window is used to evaluate the long-term effect of the event, however McWilliams and Siegel (1997) attest to complexities in controlling the effects of an event when long windows are used. Conn et al. (2004) discusses the difficulty of investigating long term effects for multiple acquisitions as subsequent takeover and other events can have significant impact on the stock returns. Post-event windows will not be considered for this study.

\subsection{Data}

The sample has been compiled using 'Data Stream' and 'Thomson-One-Banker' for UK public acquirers between 2002 and 2006. The following is the selection criteria which was also adopted by Ismail (2008): i) Deals 
that were at least1 million USD (Note 1), at the time of the announcement, are only included as lower values and are unlikely to make any significant impact to the market. Any higher deals excludes many single acquirers as Ismail (2008) found single acquirers' deals tend to be significantly lower than multiple acquirers' deal: $\$ 82$ million and \$286 million on average respectively; ii) All financial institutions are excluded due to their different nature in comparison withnon-financial institutions and acquirer firms with share price data are only included; iii) The study has been limited to completed takeover bids leading to the acquirer gaining control of the target firms (fifty-percent of the shareholding post acquisition).

With regards to multiple acquisitions, Ismail (2008) adopted several criteria from Fuller et al. (2002). Both studies considered; $(-2$ to +2$)$ as the event window and excluded 'cluster acquisitions' of two or more acquisition taking place within this five day period., an event window of $(-5$ to +5$)$ which is widely considered to check for robustness, uses an 11 day exclusion for 'cluster acquisitions'. Ismail (2008), Fuller et al. (2002) and Conn et al. (2004) sampling of multiple acquirers required firms who acquired at least two firms in a two-year window (730 days) is also used in this study..Controlling for different deal characteristics was carried out in sub-samples: target firm status (private, public or subsidiary), payment method (stock or cash), location (domestic or cross-border) and industrial scope (relatedness).

The refinement procedures yielded a final sample of 1494 deals completed by 610 unique UK acquirers. 537 deals were carried out by single acquirers of which 264 went on to make a second acquisition. 337 multiple bidding firms were identified, making an average of 3 acquisitions. The total value of all deals within this five year sample reached just over 153 billion USD, highlighting the large amount of financial resources investment in takeover activities and the vast attention paid to this area of research.

When comparing the difference in performance for single and multiple acquirers Ismail (2008) opted to designate whether a firm is regarded as a single or multiple acquirer subject to a post-event window. Therefore for this study a firm is designated as a single acquirer until it has made a second acquisition within a two year period. This implies the first deal of a sequence is categorised as a single acquirer and only sequential takeover announcements are defined as multiple acquirers.

When discussing the impact of sequential acquisitions the post-event window is used to designate whether a firm is a single or multiple acquirer. To ensure firms were correctly categorised as single or multiple, all firms were tested to check if any sequential acquisitions took place after 2006. As a result, 38 single acquirers went on to make a second deal announcement within two years post 2006, therefore were classified as multiple acquirers. Deal sequence is also investigated in thisstudy. Out of the 1494 deals between 2002 and 2006, 513 deals were part of a sequence which began before 2002. The deal order numbers were adjusted accordingly to account for this.

\subsubsection{Benchmark Models for Expected Returns}

Brown \& Warner (1980) and MacKinlay (1997) identify three main statistical models for measuring performance. The first is the mean-adjusted return model which Brown and Warner (1980) describe as a simple model that assumes the individual security risk, risk premiums and interest rates stay constant over time. However, this assumption is unrealistic and presents a major limitation. Therefore this model will not be used for the purpose of this study. The other two more common models:the market-adjusted return model; and the market model shall be applied for this study. The assumption that 'asset returns are jointly multivariate normal and independently and identically distributed through time' is imposed for these statistical models (MacKinlay, 1997).

\section{(A) Market Adjusted Return Model}

According to Brown and Warner (1980), the market adjusted return model assumes the expected returns $E_{M A}\left(R_{i t}\right)$ for security $i$ across day $t$ is constant and is indifferent to market return on event day $t:\left(R_{m, t}\right)$. Therefore, the systematic risk against the market movement is a perfect correlation $\left(\beta_{i}=1\right)$ and the unsystematic returns $\alpha_{i}$ is zero:

$$
E_{M A}\left(R_{i t}\right)=R_{m, t}
$$

Where:

$E_{M A}\left(R_{i t}\right)$ denotes the market adjusted expected returns for security $i$ on day $t$

$R_{m, t}$ is the actual market return on event day $t$.

The actual market return $\mathrm{Rm}$, $\mathrm{t}$ for event day $t$ is given by the equation:

$$
R_{m, t}=\frac{M_{i, t}-M_{i t-1}}{M P_{i t-1}}
$$


Where:

$M_{i t}$ is market index at event day $t$,

$M_{i t-l}$ is market index at event day $t-1$

(B) Market Model

According to Brown and Warner (1980) and MacKinlay (1997), the market model assumes expected returns $E_{M}\left(R_{i t}\right)$ are equal across securities $i$ for event day $t$ but are not constant. Market portfolio of risky asset $M$ is a linear combination of all securities. Thus, $R_{M, t}$ is the observed market return and $\beta_{i}$ is the sensitivity of security $i$ to the market movement. $\alpha$ is the average un-systematic returns of security $i$ over event day $t$ which is not explained by the market movement:

$$
E_{M M}\left(R_{i t}\right)=\alpha_{i}+\beta_{i} R_{m, t}
$$

Where:

$E_{M M}\left(R_{i t}\right)$ denotes the market model expected returns for security $i$ on event day $t$.

$\alpha_{i}$ is the average un-systematic returns of security $i$.

$\beta_{i}$ is the systematic component based on the sensitivity of security $i$ 's returns against the market movement.

The mean-adjusted return model does not consider security risk, risk premium or interest rate fluctuation, making it a limited benchmark model. The average un-systematic returns of securities often remains low or negligible whilst the systematic risk against market movement remains on average very close to 1 making the market adjusted model more reliable than the mean adjusted model. As a result, many studies have used the market model as it generates abnormal returns with a smaller degree of variances and correlation making for stronger statistical tests than other models. (Mackinglay, 1997). For the purpose of this study, the market return model will be used as the benchmark model.

\subsubsection{Abnormal Returns}

The expected return is what would have been experienced if the merger or acquisition had not occurred. If the event of the merger or acquisition had any impact then a difference between expected returns and actual returns would exist as the abnormal return. According to Brown and Warner (1980), to calculate the abnormal returns $A R_{i t}$ of a firm's security $i$ on event dayt, the expected return $E\left(R_{i t}\right)$ is deducted from the actual realised return $R_{i t}$ (see equation 3). A positivefigure would indicate shareholder gains; inverselya negative figure would indicate shareholder loss.

Where:

$$
A R_{i t}=R_{i t}-E_{M M}\left(R_{i t}\right)
$$

$A R_{i t}$ denotes Abnormal Return for security $i$ at event dayt

$R_{i t}$ is the Actual Return of security $i$ at event dayt

$E_{M M}\left(R_{i t}\right)$ Expected Returns of security $i$ at event day $t$ based on the market model.

And: the actual Return $R_{i t}$ of security ifor event day t is given by the equation:

$$
R_{i t}=\frac{P_{i t}-P_{i t-1}}{P_{i t-1}}
$$

Where:

$P_{i t}$ is the price of security $i$ at the end of event dayt

$P_{i t-1}$ is the price of security $i$ at the end of event dayt -1

Both coefficients $\alpha_{i}$ and $\beta_{i}$ are measured prior to the event window (i.e. estimation window see Figure 1). Abnormal returns $A R_{i t}$ exist when $\mathrm{E}\left(\mathrm{R}_{\mathrm{it}}\right) \neq \alpha_{i+} \beta_{i} R_{m, t}$, thus:

$$
A R_{i t}=R_{i t}-\left(\alpha_{i}+\beta_{i} R_{m, t}\right)
$$

Ismail (2008) utilised the market model and calculated the estimation of the abnormal return by subtracting the value-weighted market return from the firm's return. This was based on Fuller et al. (2002) argument that for multiple acquirers there is a high probability of previous takeover attempts distorting beta estimations. Ismail (2008) found the results were not altered and therefore only reported market model results. The benchmark parameters and abnormal returns are estimated in a one step process; therefore a multivariate regression model shallbe used to allow the testing of several sub-sample hypotheses. To align the results with Ismail (2008) for 
comparability, the study shall also utilise a $(-210,-21)$ estimation window for calculating the parameters $\alpha_{i}$ and $\beta_{i}$ by regressing individual firms' stock returns against the market returns.

\subsubsection{Average Abnormal Returns and Cumulative Average Abnormal Returns}

Average abnormal returns $A A R$ (equation 5) is the sum of abnormal returns ( $A R$ ) of across all firms on the same day $t$ within the event window. A cumulative average abnormal return (CAAR) (equation 6) is the sum of cumulative abnormal returns (CAR) of a firm across the event window. CAAR shall be used to determine returns over time and will be applied to several event windows to find the spread of abnormal returns.

$$
A A R_{t}=\sum_{i}^{n} A R_{i t}
$$

Where:

$A A R_{t}$ is the sum of average abnormal return of securities $i$ for $n$ number of firms on event day $t$

$$
C A A R_{t}=\sum_{t}^{n} A A R_{t}
$$

Where:

$C A A R_{t}$ is the cumulative average abnormal return of securities $i$ for $n$ number of firms on event day $t$

In an efficient capital market with no leakage of information, the share prices should immediately reflect the M\&A announcement impact on shareholders wealth. Calculating the $\mathrm{CAAR}_{\mathrm{t}}$ values of the different event windows (see section 3.5.1) will provide a sensitivity analysis and may also indicate if any leakage of information exists.

\subsection{Test Statistics}

\subsubsection{Testing Statistical Significance}

In order to test the null hypotheses, we must define what is statistically significant from "null" or "zero". Sharpe et al. (2010) discusses the difficulty of defining 'significant difference'. With the aid of a t-test the statistical significance of the abnormal returns and cumulative abnormal returns can be identified.

Table 1. Two -tailed critical value for $\mathrm{t}$

\begin{tabular}{lccc}
\hline Significant level $(\%)$ & 10 & 5 & 1 \\
Critical values for $\mathrm{t}(+/-)$ & 1.64 & 1.96 & 2.58 \\
\hline
\end{tabular}

Note. Source (itl.nist.gov; 2011): http://itl.nist.gov/div898/handbook/eda/section3/eda3672.htm, last accessed on 09.09.11.

Small sample groups (less than 30) will use critical value defined on itl.nist.gov (2011).

The null hypotheses are accepted or rejected according to the critical t-values. If the $\mathrm{t}$-value is outside the acceptance region then the null hypothesis is rejected. The critical upper and lower limit values $(+/-1.64,+/-1.96$, $+/-2.58$ ) are based on infinite sample size and are relatively consistent for large samples.

\subsubsection{Known Issues Using Daily Data and Statistical Tests}

\section{Central limit theory}

Brown and Warner $(1984,1985)$ investigated the use of daily returns for a large sample of securities. They found abnormal returns of a single security is easily identifiable but with a large sample the results converge to normal returns (central limit theory), making it difficult to identify the abnormal returns for a larger sample. The t-test attends to this issue and is used to test whether the results are significantly different from zero for large data samples(Patell, 1976).

\section{Market model parameters}

Scholes and Williams (1977) suggested biased beta regression estimates existed when daily data is used. They found share frequently traded had an upward biasedness whilst shares which rarely moved ownership had downward biased estimates. However, they also found that any biasedness in this systematic sensitivity of securities against the market movement was compensated by the unsystematic returns of the securities.

\section{Results}

\subsection{Average Abnormal Returns (AAR)}

Table 2 reports the daily $\mathrm{AAR}_{\mathrm{t}}$ of all, single and multiple UK acquirers samples for the takeover announcements event day $(\mathrm{t}=0)$ and the five days before and after. Statistically significant positive AAR are observed on the 
announcement day and the subsequent two days $(t=1,2)$ for all three categories. This indicates that on the announcement day the market perceived the takeovers, on average, as positive investments thus the share prices have reflected this in the $\mathrm{AAR}_{\mathrm{t}}$. Crucially, single acquirers obtained greater abnormal returns than multiple acquirers on the announcement day, $1.106 \%$ and $0.569 \%$ significant at $1 \%$ level respectively. This implies a difference of $0.537 \%$ at $5 \%$ level. Figure 2 provides a graphical illustration of the daily AAR for all, multiple and single acquirers on the announcement day $(\mathrm{t}=0)$ and the twenty days before and after. Both single and multiple acquirers' AAR appear relatively steady before and after the announcement, indicating insignificant informational leakage which is further discussed in section 4.4.

The following graph presents a graphical illustration of the daily average abnormal returns (AAR) for all, single and multiple UK acquirer firms from -20 days to +20days with the announcement day at $\mathrm{t}=0$ between 2002 and 2006.

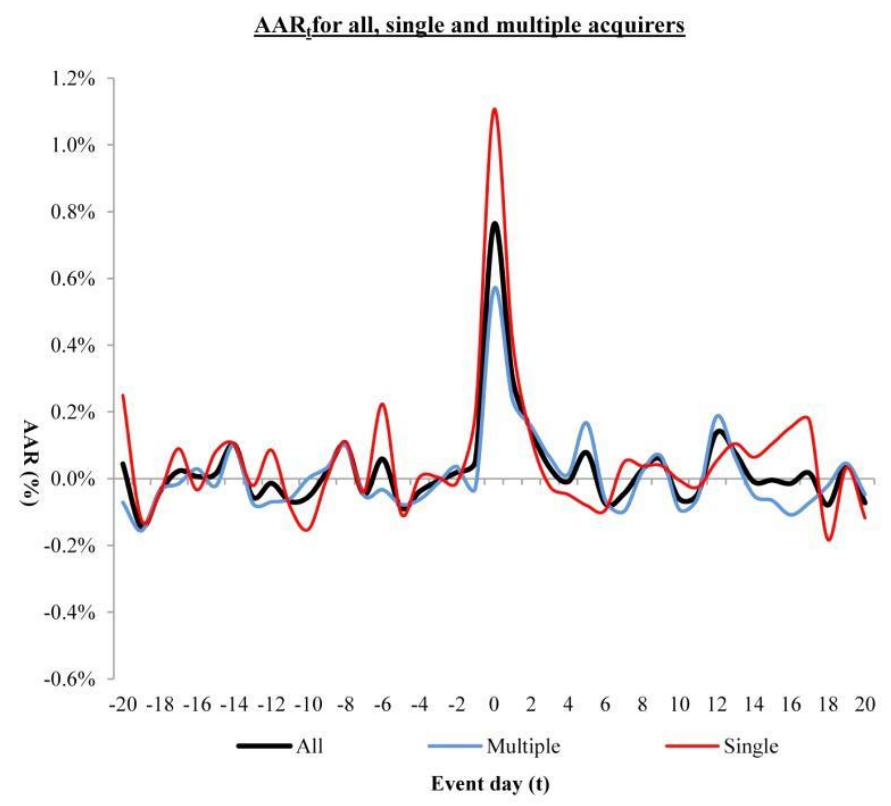

Figure 2. Average abnormal returns (AAR) for all, single and multiple acquirers

This table presents the daily average abnormal returns for all, single and multiple UK acquirers and the difference between the two for the daily event days -5 to +5 , with 0 as the announcement day. The market model was used with an estimation window of $(-210,-21)$. FTSE All market index and share prices were obtained from Datastream to estimate the parameters, $\alpha$ and $\beta$. The mean difference is based on the t-test for equality in means assuming unequal variances.

Table 2. Average abnormal returns (AAR) for acquiring firms

\begin{tabular}{|c|c|c|c|c|c|c|c|c|}
\hline \multirow{3}{*}{$\frac{\text { Day }(t)}{-5}$} & \multirow{2}{*}{\multicolumn{2}{|c|}{$\begin{array}{c}\text { All (1494 deals) } \\
\text { AAR } \\
\text { [t-stat }]\end{array}$}} & \multirow{2}{*}{\multicolumn{2}{|c|}{$\begin{array}{c}\text { Single acquirers (957 deals) } \\
\text { AAR } \\
\text { [t-stat }]\end{array}$}} & \multirow{2}{*}{\multicolumn{2}{|c|}{$\begin{array}{c}\text { Multiple acquirers (537 deals) } \\
\text { AAR } \\
\text { [t-stat] }\end{array}$}} & \multirow{2}{*}{\multicolumn{2}{|c|}{$\begin{array}{c}\text { Difference (single less multiple) } \\
\text { AAR } \\
\text { [t-stat }]\end{array}$}} \\
\hline & & & & & & & & \\
\hline & $\begin{array}{c}-0.087 \\
{[-1.5972]}\end{array}$ & $\%$ & $\begin{array}{c}-0.105 \\
{[-1.0194]}\end{array}$ & $\%$ & $\begin{array}{c}-0.077 \\
{[-1.2322]}\end{array}$ & $\% *$ & $\begin{array}{c}-0.028 \\
{[-0.2342]}\end{array}$ & $\%$ \\
\hline-4 & $\begin{array}{c}-0.038 \\
{[-0.7691]}\end{array}$ & $\%$ & $\begin{array}{c}0.005 \\
{[0.0548]}\end{array}$ & $\%$ & $\begin{array}{c}-0.062 \\
{[-1.1308]}\end{array}$ & $\%$ & $\begin{array}{c}0.068 \\
{[0.6090]}\end{array}$ & $\%$ \\
\hline-3 & $\begin{array}{c}-0.007 \\
{[-0.1214]}\end{array}$ & $\%$ & $\begin{array}{c}0.004 \\
{[0.0405]}\end{array}$ & $\%$ & $\begin{array}{c}-0.013 \\
{[-0.2003]}\end{array}$ & $\%$ & $\begin{array}{c}0.017 \\
{[0.1400]}\end{array}$ & $\%$ \\
\hline-2 & $\begin{array}{c}0.019 \\
{[0.3340]}\end{array}$ & $\%$ & $\begin{array}{c}-0.012 \\
{[-0.0996]}\end{array}$ & $\%$ & $\begin{array}{c}0.037 \\
{[0.6287]}\end{array}$ & $\%$ & $\begin{array}{c}-0.049 \\
{[-0.3624]}\end{array}$ & $\%$ \\
\hline-1 & $\begin{array}{c}0.053 \\
{[0.8283]}\end{array}$ & $\%$ & $\begin{array}{c}0.196 \\
{[1.4215]}\end{array}$ & $\%$ & $\begin{array}{c}-0.027 \\
{[-0.4316]}\end{array}$ & $\%$ & $\begin{array}{c}0.223 \\
{[1.4721]}\end{array}$ & $\%$ \\
\hline 0 & $\begin{array}{c}0.762 \\
{[7.5613]}\end{array}$ & $\begin{array}{c}\% \\
* * *\end{array}$ & $\begin{array}{c}1.106 \\
{[5.0037]}\end{array}$ & $\% * * *$ & $\begin{array}{c}0.569 \\
{[5.9073]}\end{array}$ & $\% * * *$ & $\begin{array}{c}0.537 \\
{[2.2295]}\end{array}$ & $\%^{* *}$ \\
\hline
\end{tabular}




\begin{tabular}{ccccccccc}
\hline 1 & 0.301 & $\%$ & 0.415 & $\% * *$ & 0.237 & $\% * * *$ & 0.178 & $\%$ \\
& {$[3.7702]$} & $* * *$ & {$[2.5276]$} & & {$[2.8240]$} & & {$[0.9666]$} & \\
2 & 0.146 & $\%$ & 0.126 & $\%$ & 0.158 & $\% * *$ & -0.032 & $\%$ \\
& {$[2.4381]$} & $* *$ & {$[1.1838]$} & & {$[2.1824]$} & & {$[-0.2509]$} & \\
3 & 0.033 & $\%$ & -0.022 & $\%$ & 0.065 & $\%$ & -0.087 & $\%$ \\
& {$[0.6192]$} & & {$[-0.2069]$} & & {$[1.0992]$} & & {$[-0.7090]$} & \\
4 & -0.009 & $\%$ & -0.048 & $\%$ & 0.013 & $\%$ & -0.060 & $\%$ \\
& {$[-0.1694]$} & & {$[-0.4123]$} & & {$[0.2488]$} & & {$[-0.4778]$} & \\
5 & 0.078 & $\%$ & -0.080 & $\%$ & 0.167 & $\%$ & -0.247 & $\%$ \\
\hline
\end{tabular}

$*, * *, * * *$ denotes the significance of $\mathrm{t}$-stats at the $10 \%, 5 \%$ and $1 \%$, respectively.

\subsection{Cumulative Average Abnormal Returns (CAAR)}

The following table presents the cumulative average abnormal returns for all, single and multiple UK acquirers and the difference between the two for the selected event windows (see section 3.5.1), which is calculated by cumulating the average abnormal returns found in Table 2. The market model was used with an estimation window of $(-210,-21)$. FTSE All market index and share prices were obtained from Datastream to estimate the parameters, $\alpha$ and $\beta$. The mean difference is based on the t-test for equality in means assuming unequal variances. Immediate effect is considered over the days surrounding the takeover announcement. Predetermined event window tests if prior days affect the CAAR and informational leakage is to check if any significant activity occurred before the announcement; after announcement reports for any late reaction to the announcement. Overall effect is to test the short-run event study capturing any leakage or post announcement CAAR.

Table 3. Short-run event study: Cumulative average abnormal returns (CAAR) for all, single and multiple acquirers

\begin{tabular}{|c|c|c|c|c|c|c|c|c|}
\hline \multicolumn{9}{|c|}{ Short-run event study } \\
\hline & \multicolumn{2}{|c|}{ All (1494 deals) } & \multicolumn{2}{|c|}{ Single acquirers (957 deals) } & \multicolumn{2}{|c|}{ Multiple acquirers (537 deals) } & \multicolumn{2}{|c|}{ Difference (single less multiple) } \\
\hline & CAAR & & CAAR & & CAAR & & CAAR & \\
\hline Event window & [t-stat $]$ & & [t-stat $]$ & & [t-stat $]$ & & [t-stat] & \\
\hline \multicolumn{9}{|l|}{ Immediate effect } \\
\hline$(-1,+1)$ & $\begin{array}{l}1.116 \\
{[7.5361]}\end{array}$ & $\% * * *$ & $\begin{array}{l}1.718 \\
{[5.4475]}\end{array}$ & $\% * * *$ & $\begin{array}{l}0.778 \\
{[5.2653]}\end{array}$ & $\% * * *$ & $\begin{array}{l}0.939 \\
{[2.6971]}\end{array}$ & $\% * * *$ \\
\hline$(-2,+2)$ & $\begin{array}{l}1.281 \\
{[7.4082]}\end{array}$ & $\% * * *$ & $\begin{array}{l}1.831 \\
{[4.9448]}\end{array}$ & $\% * * *$ & $\begin{array}{l}0.973 \\
{[5.6627]}\end{array}$ & $\% * * *$ & $\begin{array}{l}0.858 \\
{[2.1029]}\end{array}$ & $\% * *$ \\
\hline$(-5,+5)$ & $\begin{array}{l}1.252 \\
{[5.6583]}\end{array}$ & $\% * * *$ & $\begin{array}{l}1.585 \\
{[3.3979]}\end{array}$ & $\% * * *$ & $\begin{array}{l}1.065 \\
{[4.7261]}\end{array}$ & $\% * * *$ & $\begin{array}{l}0.520 \\
{[1.0042]}\end{array}$ & $\%$ \\
\hline \multicolumn{9}{|l|}{ Predetermined } \\
\hline$\overline{(-10,+1)}$ & $\begin{array}{l}1.086 \\
{[4.4366]}\end{array}$ & $\% * * *$ & $\begin{array}{l}1.754 \\
{[3.5363]}\end{array}$ & $\% * * *$ & $\begin{array}{l}0.711 \\
{[2.7217]}\end{array}$ & $\% * * *$ & $\begin{array}{l}1.043 \\
{[1.8603]}\end{array}$ & $\% *$ \\
\hline \multicolumn{9}{|c|}{ Informational leakage } \\
\hline$(-10,-1)$ & $\begin{array}{l}0.023 \\
{[0.1091]}\end{array}$ & $\%$ & $\begin{array}{l}0.233 \\
{[0.5373]}\end{array}$ & $\%$ & $\begin{array}{l}-0.094 \\
{[-0.4123]}\end{array}$ & $\%$ & $\begin{array}{l}0.327 \\
{[0.6676]}\end{array}$ & $\%$ \\
\hline$(-20,-1)$ & $\begin{array}{l}-0.105 \\
{[-0.3605]}\end{array}$ & $\%$ & $\begin{array}{l}0.540 \\
{[0.9314]}\end{array}$ & $\%$ & $\begin{array}{l}-0.467 \\
{[-1.4641]}\end{array}$ & $\%$ & $\begin{array}{l}1.008 \\
{[1.5221]}\end{array}$ & $\%$ \\
\hline \multicolumn{9}{|c|}{ After announcement } \\
\hline$(+1,+10)$ & $\begin{array}{l}0.453 \\
{[2.3151]}\end{array}$ & $\% * *$ & $\begin{array}{l}0.417 \\
{[1.1666]}\end{array}$ & $\%$ & $\begin{array}{l}0.473 \\
{[2.0529]}\end{array}$ & $\% * *$ & $\begin{array}{l}-0.056 \\
{[-0.1312]}\end{array}$ & $\%$ \\
\hline$(+1,+20)$ & $\begin{array}{l}0.504 \\
{[1.8780]}\end{array}$ & $\% *$ & $\begin{array}{l}0.779 \\
{[1.5300]}\end{array}$ & $\%$ & $\begin{array}{l}0.349 \\
{[1.1404]}\end{array}$ & $\%$ & $\begin{array}{l}0.430 \\
{[0.7238]}\end{array}$ & $\%$ \\
\hline \multicolumn{9}{|l|}{ Overall effect } \\
\hline$(-10,+10)$ & $\begin{array}{l}1.238 \\
{[3.9100]}\end{array}$ & $\% * * *$ & $\begin{array}{l}1.756 \\
{[2.8512]}\end{array}$ & $\% * * *$ & $\begin{array}{l}0.948 \\
{[2.6812]}\end{array}$ & $\% * * *$ & $\begin{array}{l}0.809 \\
{[1.1390]}\end{array}$ & $\%$ \\
\hline$(-20,+20)$ & $\begin{array}{l}1.160 \\
{[2.6519]}\end{array}$ & $\% * * *$ & $\begin{array}{l}2.425 \\
{[2.8324]}\end{array}$ & $\% * * *$ & $\begin{array}{l}0.450 \\
{[0.9297]}\end{array}$ & $\%$ & $\begin{array}{l}1.975 \\
{[2.0079]}\end{array}$ & $\% * *$ \\
\hline
\end{tabular}

$*, * *, * * *$ denotes the significance of $\mathrm{t}$-stats at the $10 \%, 5 \%$ and $1 \%$, respectively. 
Table 3 reports the cumulative average abnormal returns for acquirer firms across different short-run event windows for all, single and multiple acquirers. Considering the sample as a whole, there is statistically significant positive CAAR experienced by acquirer shareholders for the immediate effect $(-1,+1)$ and $(-2,+2)$. This is consistent with Ismail (2008) and Conn et al. (2004) who also reported acquirers gain wealth immediately surrounding the announcement and contradicts Sudarsanam and Mahate (2003) and Antoniou (2008)'s studies which reported wealth loss at announcement. There is also statistically significant positive CAAR for the overall short-run effect $(-10,+10)$ and $(-20,+20)$, consistent with Frank and Harris (1989).Therefore the null hypothesis $H 1_{0}$ is rejected in favour of the alternative $H_{1}$ : acquirer shareholders experience wealth gains as a result of a takeover announcement.

Additionally, there is evidence that single acquirers outperformed multiple acquirers across all event windows. For the three day period immediately surrounding the announcement $(-1,+1)$ acquirer shareholders obtain significant positive CAAR for the three categories; all, single and multiple at $1.116 \%, 1.718 \%$ and $0.778 \%$, respectively at $1 \%$ level. This is robust when testing the five day period $(-2,+2)$ and eleven day period $(-5,+5)$ also at $1 \%$ level of significance. Critically, single acquirers outperform multiple acquirers by $0.939 \%$ in the period $(-1,+1)$ and $0.858 \%$ in the period $(-2,+2)$ at significant levels, consistent with Ismail $(2008)$.

When testing the effect of predetermined movement $(-10,+1)$, CAAR increases marginally for single acquirers and decreases marginally for multiple acquirers compared to $(-1,+1)$. This indicates little or no material informational leakage and is supported by the event window studies $(-10,-1)$ and $(-20,-1)$ which report no statistically significant CAARs. The sample as a whole experience significant CAAR in the period $(-20,+20)$. However when separating the data into single and multiple acquirers, single acquirer CAAR increases to $2.425 \%$ at $1 \%$ level of significance whilst multiple acquirers do not report any statistically significant CAAR. We therefore reject the null hypothesis $\mathrm{H}_{2}$, in favour of the alternative $\mathrm{H}_{2}$ : Single acquirers experience greater wealth gains than multiple acquirers as a result of a takeover announcement.

\subsection{Sequential Deals}

\subsubsection{Effect of Deal Order Number}

This table presents the cumulative abnormal returns for single and multiple UK acquirers according to deal order. The performance is calculated using a sub-sample for the first two deals, grouping by pairs for third to tenth deal and five from the eleventh to twentieth deal, and a final sum-sample for deals order number greater than twenty.

Table 4a. Cumulative average abnormal return for acquirers by number of deals

\begin{tabular}{|c|c|c|c|c|c|c|c|}
\hline \multirow{2}{*}{$\begin{array}{l}\text { Deal order } \\
\text { Single acquirers }\end{array}$} & \multirow[t]{2}{*}{$\mathrm{N} \#$ of deals } & \multicolumn{2}{|c|}{$\begin{array}{l}(-1,+1) \\
\text { CAAR } \\
\text { [t-stat] }\end{array}$} & \multicolumn{2}{|c|}{$\begin{array}{l}(-2,+2) \\
\text { CAAR } \\
\text { [t-stat] }\end{array}$} & \multicolumn{2}{|c|}{$\begin{array}{l}(-5,+5) \\
\text { CAAR } \\
\text { [t-stat] }\end{array}$} \\
\hline & & & & & & & \\
\hline First & 293 & $\begin{array}{c}1.706 \\
{[3.6963]}\end{array}$ & $\% * * *$ & $\begin{array}{c}1.704 \\
{[3.1893]}\end{array}$ & $\% * * *$ & $\begin{array}{c}1.548 \\
{[2.1696]}\end{array}$ & $\% * *$ \\
\hline \multicolumn{8}{|l|}{ Multiple acquirers } \\
\hline First & 264 & $\begin{array}{c}1.729 \\
{[4.0290]}\end{array}$ & $\% * * *$ & $\begin{array}{c}1.962 \\
{[3.8668]}\end{array}$ & $\% * * *$ & $\begin{array}{c}1.624 \\
{[2.7140]}\end{array}$ & $\% * * *$ \\
\hline Second & 254 & $\begin{array}{c}1.485 \\
{[5.3959]}\end{array}$ & $\% * * *$ & $\begin{array}{c}1.682 \\
{[5.0429]}\end{array}$ & $\% * * *$ & $\begin{array}{c}2.044 \\
{[3.9583]}\end{array}$ & $\% * * *$ \\
\hline Third-Fourth & 234 & $\begin{array}{c}0.886 \\
{[2.7968]}\end{array}$ & $\% * * *$ & $\begin{array}{c}1.003 \\
{[2.6605]}\end{array}$ & $\% * * *$ & $\begin{array}{c}1.167 \\
{[2.4281]}\end{array}$ & $\% * *$ \\
\hline Fifth-Sixth & 122 & $\begin{array}{c}1.275 \\
{[2.7975]}\end{array}$ & $\% * * *$ & $\begin{array}{c}1.339 \\
{[2.4014]}\end{array}$ & $\% * *$ & $\begin{array}{c}1.366 \\
{[2.7442]}\end{array}$ & $\% * * *$ \\
\hline Seventh-Eight & 83 & $\begin{array}{c}0.641 \\
{[1.0566]}\end{array}$ & $\%$ & $\begin{array}{c}0.807 \\
{[1.3485]}\end{array}$ & $\%$ & $\begin{array}{c}0.488 \\
{[0.6285]}\end{array}$ & $\%$ \\
\hline Ninth-Tenth & 59 & $\begin{array}{c}0.531 \\
{[1.1007]}\end{array}$ & $\%$ & $\begin{array}{c}0.573 \\
{[1.0340]}\end{array}$ & $\%$ & $\begin{array}{c}0.780 \\
{[1.1333]}\end{array}$ & $\%$ \\
\hline Eleventh-Fifteenth & 103 & $\begin{array}{c}-0.679 \\
{[-1.5663]}\end{array}$ & $\%$ & $\begin{array}{c}-0.375 \\
{[-0.8890]}\end{array}$ & $\%$ & $\begin{array}{c}-0.579 \\
{[-1.1029]}\end{array}$ & $\%$ \\
\hline Sixteenth-Twentieth & 52 & $\begin{array}{c}0.419 \\
{[1.1184]}\end{array}$ & $\%$ & $\begin{array}{c}0.584 \\
{[1.1000]}\end{array}$ & $\%$ & $\begin{array}{c}-0.072 \\
{[-0.1009]}\end{array}$ & $\%$ \\
\hline Higher than Twentieth & 50 & $\begin{array}{c}-0.630 \\
{[-1.4542]}\end{array}$ & $\%$ & $\begin{array}{c}0.257 \\
{[0.3989]}\end{array}$ & $\%$ & $\begin{array}{c}0.248 \\
{[0.3501]}\end{array}$ & $\%$ \\
\hline
\end{tabular}

$*, * *, * * *$ denotes the significance of t-stats at the $10 \%, 5 \%$ and $1 \%$, respectively. 
Table 4a reports the impact of the deal order number on acquirers' return. Multiple acquirers outperform single acquirers for the first deal, particularly for the event window $(-2,+2)$. In contrast Ismail's (2008) findings found single acquirers outperform multiple acquirers for the first deal. In an attempt to deduce an explanation, Conn et al.(2004) suggest that the failure of first acquisitions deter some from acquiring again. Therefore, multiple acquirers on average have a greater first-success rate. Table $4 \mathrm{~b}$ supports this and finds $48 \%$ of single acquirers fail whilst only $40 \%$ of first deals of multiple acquirers fail (for the period $-2,+2$ ). Table $4 \mathrm{a}$ also reports that all sequential acquisitions generate lower CAAR than the first acquisitions with the one exception, the second deal number for the event window $(-5,+5)$,supporting the hubris hypothesis.

Positive returns continue up to the tenth deal but are not statistically significant, whereas Ismail (2008) found negligible or negative returns from the seventh deal onwards. As a whole, there is a declining pattern (see Figure 3 ) from the first through to fifteenth acquisition. That is CAAR decreases from $1.962 \%$ to $-0.375 \%$ for event window $(-2,+2)$. These results are consistent with the diminishing returns hypothesis which stipulates best opportunities are realised in the primary acquisitions This is coherent with the findings of Ismail (2008) and Conn et al. (2004). Whilst multiple acquirers do not generate as much returns compared to single acquirers, Table 4a shows that there is still realisable wealth gain potential. It is only once acquirers have carried out seven or more takeovers that the returns are insignificant.

Graphical illustration of cumulative average abnormal returns (CAAR) by deal number for UK acquirer firms between 2002 and 2006 over the event windows $(-2,+2) ;(-1,+1) ;(-5,+5)$.Due to the limited number of deals beyond the third, sub-samples are divided into first and second deals, deals between third and tenth into pairs, deals between eleventh and twentieth into fives, twentieth onwards.

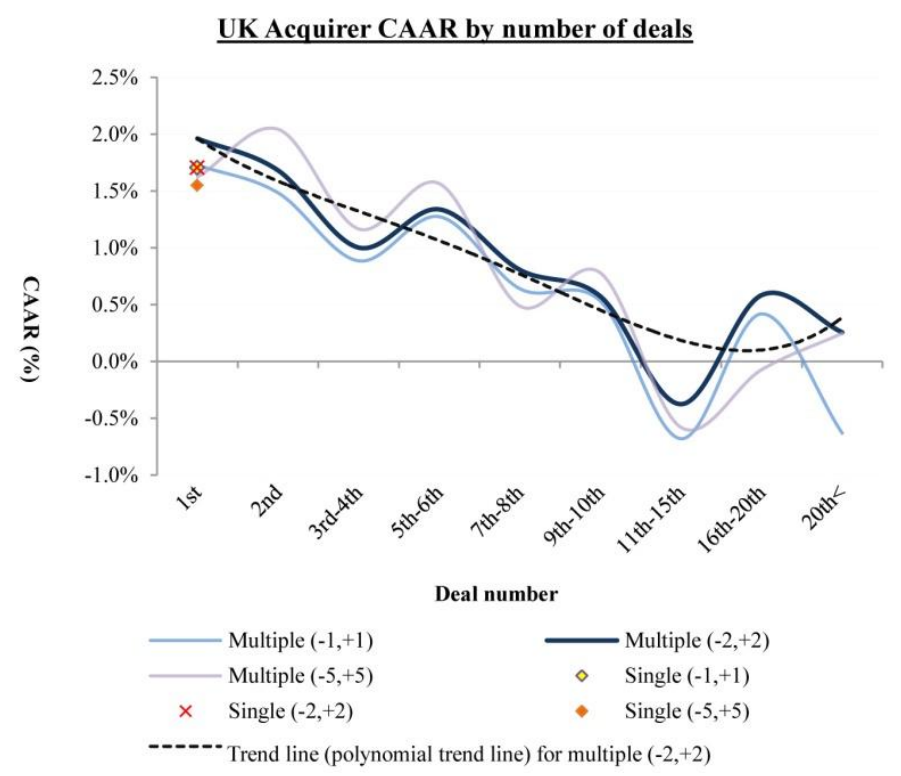

Figure 3. Cumulative average abnormal returns (CAAR) by deal number

\subsubsection{Successful/Unsuccessful First Time Acquirers}

$H 3_{O a}$ states there is no wealth increase/decrease for sequential acquisitions for successful/unsuccessful first time acquirers. Since Figure 3 shows $H_{3}$ is rejected, the research goes on to inspect whether the decrease in sequential acquisition in Table $4 \mathrm{a}$ is stronger for multiple acquiring firms with either an unsuccessful first acquisition (negative gains for first deal) or a successful first acquisition (positive gains for first deal).

This table presents the cumulative abnormal returns for single and multiple UK acquirers according to the success of the first acquisition. Panel A reports the results based on successful first merger deal orders with sub-samples for each of the first three deal order number and an additional sub-sample groups for deals fourth onwards. A final sub-sample of all acquisitions is presented. Panel B reports the results based on unsuccessful first merger deal orders with sub-samples similar topanel A. 
Table $4 \mathrm{~b}$. Cumulative average abnormal returns for the successful/unsuccessful first merger deals and sequential deals for the event window $(-1,+1) ;(-2,+2) ;(-5,+5)$

\begin{tabular}{|c|c|c|c|c|c|c|c|c|c|}
\hline \multirow{2}{*}{\multicolumn{2}{|c|}{$\begin{array}{l}\text { Deal order } \quad \text { N\# of deals } \\
\underline{\text { Panel A.Successful first merger dea }}\end{array}$}} & \multicolumn{2}{|c|}{$\begin{array}{c}(-1,+1) \\
\text { CAAR \% } \\
\text { [t-stat] }\end{array}$} & $\mathrm{N \#}$ of deals & \multicolumn{2}{|c|}{$\begin{array}{c}(-2,+2) \\
\text { CAAR \% } \\
\text { [t-stat] }\end{array}$} & $\mathrm{N \#}$ of deals & \multicolumn{2}{|c|}{$\begin{array}{c}(-5,+5) \\
\text { CAAR \% } \\
\text { [t-stat] }\end{array}$} \\
\hline & & & & & & & & & \\
\hline \multicolumn{10}{|c|}{ Single acquirers } \\
\hline First (i.e. all) & 155 & $\begin{array}{l}5.853 \\
{[10.9449]}\end{array}$ & $\% * * *$ & 142 & $\begin{array}{l}7.023 \\
{[10.1268]}\end{array}$ & $\% * * *$ & 140 & $\begin{array}{l}9.083 \\
{[10.3522]}\end{array}$ & $\% * * *$ \\
\hline \multicolumn{10}{|c|}{ Multiple acquirers } \\
\hline First & 129 & $\begin{array}{l}4.771 \\
{[7.9601]}\end{array}$ & $\% * * *$ & 133 & $\begin{array}{l}5.935 \\
{[8.7839]}\end{array}$ & $\% * * *$ & 120 & $\begin{array}{l}7.979 \\
{[10.9992]}\end{array}$ & $\% * * *$ \\
\hline Second & 129 & $\begin{array}{l}1.379 \\
{[4.9781]}\end{array}$ & $\% * * *$ & 133 & $\begin{array}{l}1.346 \\
{[3.3344]}\end{array}$ & $\% * * *$ & 120 & $\begin{array}{l}1.012 \\
{[1.6227]}\end{array}$ & $\%$ \\
\hline Third & 56 & $\begin{array}{l}-0.169 \\
{[-0.2906]}\end{array}$ & $\%$ & 62 & $\begin{array}{l}0.040 \\
{[0.0633]}\end{array}$ & $\%$ & 56 & $\begin{array}{l}0.718 \\
{[0.9745]}\end{array}$ & $\%$ \\
\hline Fourth + & 77 & $\begin{array}{l}0.987 \\
{[2.2081]}\end{array}$ & $\% * *$ & 92 & $\begin{array}{l}1.294 \\
{[3.1796]}\end{array}$ & $\% * * *$ & 84 & $\begin{array}{l}1.095 \\
{[1.8870]}\end{array}$ & $\% *$ \\
\hline All & 391 & $\begin{array}{l}2.199 \\
{[8.2718]}\end{array}$ & $\% * * *$ & 420 & $\begin{array}{l}2.598 \\
{[8.5951]}\end{array}$ & $\% * * *$ & 380 & $\begin{array}{l}3.187 \\
{[8.3219]}\end{array}$ & $\% * * *$ \\
\hline \multicolumn{10}{|c|}{$\begin{array}{l}\text { Panel B. Unsuccessful first merger deal } \\
\text { Single acquirers }\end{array}$} \\
\hline First (i.e. all) & 118 & $\begin{array}{l}-3.741 \\
{[-8.2687]}\end{array}$ & $\% * * *$ & 131 & $\begin{array}{l}-4.061 \\
{[-9.3592]}\end{array}$ & $\% * * *$ & 133 & $\begin{array}{l}-6.373 \\
{[-10.4983]}\end{array}$ & $\% * * *$ \\
\hline \multicolumn{10}{|c|}{ Multiple acquirers } \\
\hline First & 95 & $\begin{array}{l}-2.319 \\
{[-6.7562]}\end{array}$ & $\% * * *$ & 91 & $\begin{array}{l}-3.838 \\
{[-7.5267]}\end{array}$ & $\% * * *$ & 104 & $\begin{array}{l}-5.644 \\
{[-9.9150]}\end{array}$ & $\% * * *$ \\
\hline Second & 95 & $\begin{array}{l}1.107 \\
{[2.1552]}\end{array}$ & $\% * *$ & 91 & $\begin{array}{l}1.749 \\
{[2.9420]}\end{array}$ & $\% * * *$ & 104 & $\begin{array}{l}2.691 \\
{[3.0707]}\end{array}$ & $\% * * *$ \\
\hline Third & 43 & $\begin{array}{l}0.185 \\
{[1.6047]}\end{array}$ & $\%$ & 37 & $\begin{array}{l}0.888 \\
{[1.0544]}\end{array}$ & $\%$ & 43 & $\begin{array}{l}-0.023 \\
{[-0.0267]}\end{array}$ & $\%$ \\
\hline Fourth + & 46 & $\begin{array}{l}1.781 \\
{[3.0224]}\end{array}$ & $\% * * *$ & 31 & $\begin{array}{l}1.825 \\
{[2.1407]}\end{array}$ & $\% * *$ & 39 & $\begin{array}{l}2.159 \\
{[2.2965]}\end{array}$ & $\% * *$ \\
\hline All & 279 & $\begin{array}{l}0.064 \\
{[0.2295]}\end{array}$ & $\%$ & 250 & $\begin{array}{l}-0.402 \\
{[-1.0985]}\end{array}$ & $\%$ & 290 & $\begin{array}{l}-0.772 \\
{[-1.6460]}\end{array}$ & $\% * * *$ \\
\hline
\end{tabular}

$*, * *, * * *$ denotes the significance of $\mathrm{t}$-stats at the $10 \%, 5 \%$ and $1 \%$, respectively.

Table $4 \mathrm{~b}$ presents the CAAR for single and multiple UK acquirers according to the success of the first acquisition. Panel A reports the results based on successful first merger deal orders with sub-samples for each of the first three deal order number and an additional sub-sample group for the $4^{\text {th }}$ deal onwards. A sub-sample of all acquisitions is presented for both single and multiple merger deals. Panel B reports the results based on unsuccessful first merger deal orders with the same sub-sample format as panel A. This requires deal sequences from the first deal onwards, therefore deal sequences which began after $1^{\text {st }}$ January 2002 with a hiatus of two years are only considered so that the first deal 'successfulness' is correctly identified. This left a sample of 264 unique multiple bidder firms acquiring 670 targets. Single acquirer sample was left unchanged.

Panel A and B indicate successful single acquirers on average performed noticeably better than successful first deals of multiple acquirers (approximately 1\% higher CAAR across all three event windows), and unsuccessful single acquirers performed worse than multiple acquirers' first deal but the difference is noticeable across the three event windows $(1.4 \%, 0.2 \%, 0.8 \%$ worse for the event windows $(-1,+1) ;(-2,+2) ;(-5,+5)$ respectively).

Panel A shows management of multiple acquirers, with a successful first takeover, appear overconfident as the second acquisition CAAR is considerably lower and the third even lower, consistent with the hubris hypothesis and findings by Conn et al. (2004). The fourth deal onwards report an increase in CAAR that is statistically significant, indicating a shift from hubris to learning hypothesis. It appears management learn from their experience when suffering from hubris after their third acquisition and this pattern is robust for all three event windows (see Figure A1).This is in contrast to Ismail (2008)'s study which found successful acquirers after the third acquisition even though negligible CAAR are reported signalling the hubris hypothesis. 
Panel B shows multiple acquirers with an unsuccessful first takeover bid of $-3.838 \%(-2,+2)$ learn from their previous experience and posted an average of $1.749 \%(-2,+2)$ returns for their second deal, both significant at $1 \%$ level. This is robust with the event windows $(-1,+1)$ and $(-5,+5)$ and consistent with the organisational learning hypothesis and the findings of Ismail (2008) and Conn et al. (2004). However, the third merger deal appears insignificant and this corresponds to Aktas et al. (2007) findings that despite an initial gain from between deal one and two, the third declines due to other factors outlined in diminishing returns and hubris hypothesis (see Figure A4).

The CAAR of the fourth merger deal onwards appears to favour firms who had an unsuccessful first deal compared to firms with a successful first deal and is robust for all three event windows. This indicates unsuccessful first time acquirers may support better success for their latter acquisitions than successful first time acquirers.

Reflecting the finding from Table $4 \mathrm{~b}, H 3_{o b}$ can be rejected in favour of $H 3_{l b}$ : Successful first time acquirers experience wealth decrease for sequential acquisitions but record an increase after the third acquisition; and unsuccessful first time acquirers experience wealth increase for the second acquisition but wealth decrease from the third onwards.

\subsection{Effect of Deal Characteristics}

\subsubsection{Acquirer Wealth Gain by Payment Method}

The following table presents the cumulative average abnormal returns by all cash, all equity and difference for all, single and multiple UK acquirers and the difference between the two for the selected event windows $(-1,+1)$; $(-2,+2) ;(-5,+5)$. The market model was used with an estimation window of $(-210,-21)$. FTSE All market index and share prices were obtained from Datastream to estimate the parameters, alpha $\alpha$ and beta $\beta$. Effect of payment method is the difference in returns between cash and equity deals. The mean difference and effect of payment method is based on the t-test for equality in means assuming unequal variances. Only all cash deals and equity deals are considered, with a final total sample of 1195 . Panel A shows the difference in performance between single and multiple acquirers, whilst panel B shows the difference in cash and equity performance.

Table 5a. Cumulative average abnormal returns (CAAR) for all, single and multiple acquirers by payment method

\begin{tabular}{|c|c|c|c|c|c|c|c|c|}
\hline & \multicolumn{2}{|l|}{ All } & \multicolumn{2}{|c|}{ Single acquirers } & \multicolumn{2}{|c|}{ Multiple acquirers } & \multicolumn{2}{|c|}{ Difference (single less multiple } \\
\hline $\begin{array}{l}\text { Payment } \\
\text { method }\end{array}$ & $\begin{array}{l}\text { CAAR } \\
\text { [t-stat] }\end{array}$ & & $\begin{array}{l}\text { CAAR } \\
\text { [t-stat] }\end{array}$ & & $\begin{array}{l}\text { CAAR } \\
\text { [t-stat] }\end{array}$ & & $\begin{array}{l}\text { CAAR } \\
\text { [t-stat] }\end{array}$ & \\
\hline \multicolumn{9}{|c|}{ Panel A. Difference in performance between single and multiple acquirers } \\
\hline Cash deals (No.\#) & $(843)$ & & $(282)$ & & $(561)$ & & & \\
\hline$(-1,+1)$ & $\begin{array}{c}0.829 \\
{[4.4933]}\end{array}$ & $\% * * *$ & $\begin{array}{c}1.546 \\
{[3.5945]}\end{array}$ & $\% * * *$ & $\begin{array}{c}0.469 \\
{[2.7258]}\end{array}$ & $\% * * *$ & $\begin{array}{c}1.077 \\
{[2.3254]}\end{array}$ & $\% * *$ \\
\hline$(-2,+2)$ & $\begin{array}{c}0.922 \\
{[4.3629]}\end{array}$ & $\% * * *$ & $\begin{array}{c}1.620 \\
{[3.2068]}\end{array}$ & $\% * * *$ & $\begin{array}{c}0.571 \\
{[3.0155]}\end{array}$ & $\% * * *$ & $\begin{array}{c}1.049 \\
{[1.9441]}\end{array}$ & $\% *$ \\
\hline$(-5,+5)$ & $\begin{array}{c}1.028 \\
{[3.7365]}\end{array}$ & $\% * * *$ & $\begin{array}{c}1.652 \\
{[2.5804]}\end{array}$ & $\% * *$ & $\begin{array}{c}0.715 \\
{[2.7575]}\end{array}$ & $\% * *$ & $\begin{array}{c}0.938 \\
{[1.3576]}\end{array}$ & $\%$ \\
\hline Equity deals(No.\#) & $(352$ & & (155) & & (197) & & & \\
\hline$(-1,+1)$ & $\begin{array}{c}1.648 \\
{[4.7587]}\end{array}$ & $\% * * *$ & $\begin{array}{c}2.540 \\
{[4.2304]}\end{array}$ & $\% * * *$ & $\begin{array}{c}0.946 \\
{[2.4016]}\end{array}$ & $\% * *$ & $\begin{array}{c}1.594 \\
{[2.2202]}\end{array}$ & $\% * *$ \\
\hline$(-2,+2)$ & $\begin{array}{c}1.617 \\
{[4.1219]}\end{array}$ & $\% * * *$ & $\begin{array}{c}2.289 \\
{[3.4099]}\end{array}$ & $\% * * *$ & $\begin{array}{c}1.088 \\
{[2.3712]}\end{array}$ & $\% * *$ & $\begin{array}{c}1.201 \\
{[1.4774]}\end{array}$ & $\%$ \\
\hline$(-5,+5)$ & $\begin{array}{c}1.146 \\
{[2.1699]}\end{array}$ & $\% * *$ & $\begin{array}{c}1.571 \\
{[1.7036]}\end{array}$ & $\% * *$ & $\begin{array}{c}0.812 \\
{[1.3425]}\end{array}$ & $\%$ & $\begin{array}{c}0.759 \\
{[0.6884]}\end{array}$ & $\%$ \\
\hline Panel B.Effect of $p$ & yment metho & $d$, differ & in cash ande & uity per & nance (cash l & sequity & panel A) & \\
\hline$(-1,+1)$ & $\begin{array}{c}-0.819 \\
{[-2.0868]}\end{array}$ & $\% * *$ & $\begin{array}{c}-0.994 \\
{[-1.6463]}\end{array}$ & $\% *$ & $\begin{array}{c}-0.477 \\
{[-1.1101]}\end{array}$ & $\%$ & & \\
\hline$(-2,+2)$ & $\begin{array}{c}-0.695 \\
{[-1.6590]}\end{array}$ & $\% *$ & $\begin{array}{c}-0.669 \\
{[-0.7959]}\end{array}$ & $\%$ & $\begin{array}{c}-0.517 \\
{[-1.0408]}\end{array}$ & $\%$ & & \\
\hline$(-5,+5)$ & $\begin{array}{c}-0.118 \\
{[-0.1978]}\end{array}$ & $\%$ & $\begin{array}{c}0.081 \\
{[0.0726]}\end{array}$ & $\%$ & $\begin{array}{c}-0.097 \\
{[-0.1479]}\end{array}$ & $\%$ & & \\
\hline
\end{tabular}

$*, * *, * * *$ denotes the significance of t-stats at the $10 \%, 5 \%$ and $1 \%$, respectively. 
To determine whether payment method has an impact on acquirer wealth, immediate to the announcement event, Table 5a reports the effect of payment method for all, single and multiple acquirers. Panel A displays the difference in performance between single and multiple acquirers whilst panel B shows the difference in cash and equity performance. Only all cash deals and all equity deals are considered, with a final total sample of 1195out of which $71 \%$ were cash deals and $29 \%$ equity deals.

Panel A shows equity deals and cash deals both report statistically significant abnormal returns across the sample groups and is robust for the three event windows. Greater abnormal returns are observed for equity deals than cash deals. This conflicts with the general consensus that cash deals result in greater abnormal returns (see Moeller et al., 2004; Sudarsanam \& Mahate, 2006; Loughran \& Vijh, 1997). In addition, the cash deal abnormal returns appear to increase as the event window days increase from $(-1,+1)$ to $(-5,+5)$ whereas the equity deal abnormal returns appear to decrease. Consequently, an additional test for a longer event window $(-20,+20)$ was tested to see if this trend continues and whether the results across a larger event window match the general consensus.

Table $5 \mathrm{~b}$ shows, across a longer event window, cash deals outperform equity deals by $1.172 \%$ and $0.051 \%$ respectively however the difference is not statistically significant. An explanation as to why the pattern changes over time could be because equity deals are primarily financed by debt which investors prefer as debt financing is cheaper, however debt financing also indicates lack of cash flows and it appears investors become aware of this as time progresses. Since the difference between payment methods are not consistent or statistically significant for all three sample groups we accept the null hypothesis $H 4_{0 a}$ : acquirer shareholder return is not affected by payment method.

Single acquirers outperform multiple acquirers in cash and equity deals across all four event windows and is statistically significant for $(-1,+1)$ and $(-20,+20)$ consistent with Ismail (2008). Therefore the null hypothes is $H 5_{I b}$ is rejected in favour of the alternative $H 5_{0 b}$ : any difference in abnormal returns between shareholders of single and multiple acquirers is affected by method of payment.

This table presents the cumulative average abnormal returns by all cash, all equity and difference for all, single and multiple UK acquirers and the difference between the two. The market model was used with an estimation window of $(-210,-21)$. FTSE All market index and share prices were obtained from Datastream to estimate the parameters, alpha $\alpha$ and beta $\beta$. Effect of payment method is the difference in returns between cash and equity deals. The mean difference and effect of payment method is based on the t-test for equality in means assuming unequal variances. Only all cash deals and equity are considered, with a final total sample of 1195 . Panel A shows the difference in performance between single and multiple acquirers, whilst panel B shows the difference in cash and equity performance.

Table 5b. Cumulative average abnormal returns (CAAR) for all, single and multiple acquirers by payment method $(-20,+20)$

\begin{tabular}{|c|c|c|c|c|c|c|c|c|}
\hline \multirow[b]{2}{*}{$\begin{array}{l}\text { Payment } \\
\text { method }\end{array}$} & \multicolumn{2}{|c|}{ All } & \multicolumn{2}{|c|}{ Single acquirers } & \multicolumn{2}{|c|}{ Multiple acquirers } & \multicolumn{2}{|c|}{ Difference (single less multiple) } \\
\hline & \multicolumn{2}{|c|}{$\begin{array}{l}\text { CAAR } \\
\text { [t-stat] }\end{array}$} & \multicolumn{2}{|c|}{$\begin{array}{l}\text { CAAR } \\
\text { [t-stat] }\end{array}$} & \multicolumn{2}{|c|}{$\begin{array}{l}\text { CAAR } \\
\text { [t-stat] }\end{array}$} & \multicolumn{2}{|c|}{$\begin{array}{l}\text { CAAR } \\
\text { [t-stat] }\end{array}$} \\
\hline \multicolumn{9}{|c|}{ Panel A. Difference in performance between single and multiple acquirers } \\
\hline Cash deals (No.\#) & $(843)$ & & $(282$ & & $(56$ & & & \\
\hline$(-20,+20)$ & $\begin{array}{c}1.172 \\
{[2.0698]}\end{array}$ & $\% * *$ & $\begin{array}{c}2.591 \\
{[2.1561]}\end{array}$ & $\% * *$ & $\begin{array}{c}0.458 \\
{[0.7668]}\end{array}$ & $\%$ & $\begin{array}{c}2.133 \\
{[1.8050]}\end{array}$ & $\% *$ \\
\hline Equity deals(No.\#) & $(352)$ & & $(155$ & & $(19$ & & & \\
\hline$(-20,+20)$ & $\begin{array}{c}-0.051 \\
{[0.0504]}\end{array}$ & $\%$ & $\begin{array}{c}2.031 \\
{[1.6596]}\end{array}$ & $\% *$ & $\begin{array}{c}-1.689 \\
{[1.7159]}\end{array}$ & $\% *$ & $\begin{array}{c}3.720 \\
{[1.6892]}\end{array}$ & $\% *$ \\
\hline \multicolumn{9}{|c|}{ Panel B.Effect of payment method, difference in cash and equity performance (cash less equity from panel A) } \\
\hline$(-20,+20)$ & $\begin{array}{c}1.223 \\
{[1.0535]}\end{array}$ & $\%$ & $\begin{array}{c}0.561 . \\
{[0.2787]}\end{array}$ & $\%$ & $\begin{array}{c}2.147 \\
{[1.5166]}\end{array}$ & $\%$ & & \\
\hline
\end{tabular}

$*, * *, * * *$ denotes the significance of t-stats at the $10 \%, 5 \%$ and $1 \%$, respectively.

Table $5 \mathrm{c}$ gives a further breakdown of payment method by target type and yields interesting findings. Only $1 \%$ of cash deals are for public targets and no significant gains or losses are reported. 9\% of equity deals are for public targets generating statistical negative abnormal returns for the three event windows, varying from $-2.306 \%$ to $-3.013 \%$. Takeovers of private and subsidiary firms by cash and equity yield significant abnormal returns but equity deals outperform cash deals. This finding is robust for the three, five and eleven days surrounding the 
announcement event day. These findings are similar to Ismail (2008) who also found equity deals for subsidiaries yielded the highest abnormal returns. This could be attributed to acquirer gaining part-ownership of the target before the takeover, also referred to as pre-merger toehold ownership. In these situations management benefit from paying significantly lower premiums (Ismail, 2008).

Table 5c. Cumulative average abnormal returns (CAAR) for takeovers of different target statusby payment method

\begin{tabular}{|c|c|c|c|c|c|c|c|c|}
\hline \multirow{4}{*}{$\begin{array}{l}\text { Payment } \\
\text { method } \\
\text { Cash deals (No.\#) } \\
(-1,+1)\end{array}$} & \multirow{2}{*}{\multicolumn{2}{|c|}{$\begin{array}{c}\text { All } \\
\text { CAAR } \\
\text { [t-stat] }\end{array}$}} & \multirow{2}{*}{\multicolumn{2}{|c|}{$\begin{array}{l}\text { Public } \\
\text { CAAR } \\
\text { [t-stat] }\end{array}$}} & \multicolumn{2}{|c|}{ Private } & \multicolumn{2}{|c|}{ Subsidiary } \\
\hline & & & & & & & & \\
\hline & \multicolumn{2}{|c|}{ (843) } & \multicolumn{2}{|c|}{$(15)$} & \multicolumn{2}{|c|}{$(620)$} & \multicolumn{2}{|c|}{ (208) } \\
\hline & $\begin{array}{c}0.829 \\
{[4.4933]}\end{array}$ & $\% * * *$ & $\begin{array}{c}0.697 \\
{[0.4782]}\end{array}$ & $\%$ & $\begin{array}{c}0.854 \\
{[3.9125]}\end{array}$ & $\% * * *$ & $\begin{array}{c}0.765 \\
{[2.1517]}\end{array}$ & $\% * *$ \\
\hline$(-2,+2)$ & $\begin{array}{c}0.922 \\
{[4.3629]}\end{array}$ & $\% * * *$ & $\begin{array}{c}-0.011 \\
{[-0.0076]}\end{array}$ & $\%$ & $\begin{array}{c}0.906 \\
{[3.6635]}\end{array}$ & $\% * * *$ & $\begin{array}{c}1.038 \\
{[2.4443]}\end{array}$ & $\% * *$ \\
\hline$(-5,+5)$ & $\begin{array}{c}1.028 \\
{[3.7365]}\end{array}$ & $\% * * *$ & $\begin{array}{c}-0.524 \\
{[-0.3175]}\end{array}$ & $\%$ & $\begin{array}{c}1.036 \\
{[3.2016]}\end{array}$ & $\% * * *$ & $\begin{array}{c}1.118 \\
{[2.0358]}\end{array}$ & $\% * *$ \\
\hline Equity deals (No.\#) & \multicolumn{2}{|c|}{ (352) } & \multicolumn{2}{|c|}{ (33) } & \multicolumn{2}{|c|}{$(265)$} & \multicolumn{2}{|c|}{ (54) } \\
\hline$(-1,+1)$ & $\begin{array}{c}1.648 \\
{[4.7587]}\end{array}$ & $\% * * *$ & $\begin{array}{c}-2.306 \\
{[-2.2092]}\end{array}$ & $\% * *$ & $\begin{array}{c}1.945 \\
{[5.0379]}\end{array}$ & $\% * * *$ & $\begin{array}{c}2.607 \\
{[2.7090]}\end{array}$ & $\% * * *$ \\
\hline$(-2,+2)$ & $\begin{array}{c}1.617 \\
{[4.1219]}\end{array}$ & $\% * * *$ & $\begin{array}{c}-2.332 \\
{[-1.9468]}\end{array}$ & $\% *$ & $\begin{array}{c}2.076 \\
{[4.5504]}\end{array}$ & $\% * * *$ & $\begin{array}{c}1.779 \\
{[1.9561]}\end{array}$ & $\% *$ \\
\hline$(-5,+5)$ & $\begin{array}{c}1.146 \\
{[2.1699]}\end{array}$ & $\% * *$ & $\begin{array}{c}-3.013 \\
{[-1.7129]}\end{array}$ & $\% *$ & $\begin{array}{c}1.476 \\
{[2.5026]}\end{array}$ & $\% * *$ & $\begin{array}{c}2.071 \\
{[1.4032]}\end{array}$ & $\%$ \\
\hline
\end{tabular}

$*, * *, * * *$ denotes the significance of $\mathrm{t}$-stats at the $10 \%, 5 \%$ and $1 \%$, respectively.

This table presents the cumulative average abnormal returns by all cash and all equity for the three target statuses: public, private and subsidiary. The market model was used with an estimation window of $(-210,-21)$. FTSEAll market index and share prices were obtained from Datastream to estimate the parameters, alpha $\alpha$ and beta $\beta$. Effect of payment method is the difference in returns between cash and equity deals. The mean difference and effect of payment method is based on the t-test for equality in means assuming unequal variances. Only all cash deals and equity deals are considered, with a final total sample of 1195 .

\subsubsection{Acquirer Wealth Gain by Target Status}

This table presents the cumulative average abnormal returns by public, private and subsidiary for all, single and multiple UK acquirers and the difference between the two for the selected event windows $(-1,+1) ;(-2,+2)$; $(-5,+5)$. The market model was used with an estimation window of $(-210,-21)$. FTSEAll market index and share prices were obtained from Datastream to estimate the parameters, alpha $\alpha$ and beta $\beta$. The mean difference and effect of payment method is based on the t-test for equality in means assuming unequal variances.

Table 6. Cumulative average abnormal returns (CAAR) for all, single and multiple acquirers by target type

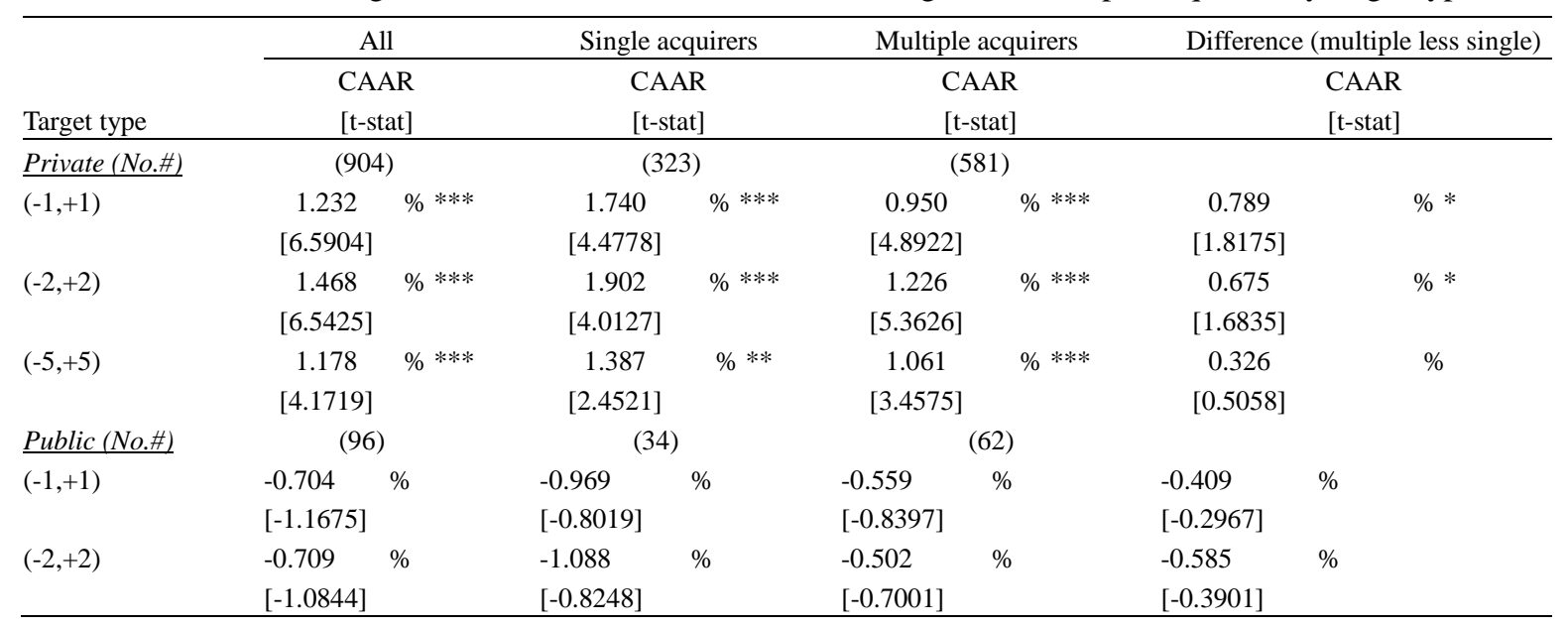




\begin{tabular}{|c|c|c|c|c|c|c|c|c|}
\hline$(-5,+5)$ & $\begin{array}{l}-0.919 \\
{[-1.1080]}\end{array}$ & $\%$ & $\begin{array}{l}-2.535 \\
{[-1.3221]}\end{array}$ & $\%$ & $\begin{array}{l}-0.033 \\
{[-0.0454]}\end{array}$ & $\%$ & $\begin{array}{l}-2.502 \\
{[-1.2195]}\end{array}$ & $\%$ \\
\hline Subsidiary (No.\#) & (494) & & $(18$ & & & 14) & & \\
\hline$(-1,+1)$ & $\begin{array}{l}1.257 \\
{[4.7979]}\end{array}$ & $\% * * *$ & $\begin{array}{l}2.185 \\
{[3.7412]}\end{array}$ & $\% * * *$ & $\begin{array}{l}0.724 \\
{[3.0701]}\end{array}$ & $\% * * *$ & $\begin{array}{l}1.461 \\
{[2.3188]}\end{array}$ & $\% * *$ \\
\hline$(-2,+2)$ & $\begin{array}{l}1.327 \\
{[4.4845]}\end{array}$ & $\% * * *$ & $\begin{array}{l}2.256 \\
{[3.4423]}\end{array}$ & $\% * * *$ & $\begin{array}{l}0.795 \\
{[2.9266]}\end{array}$ & $\% * * *$ & $\begin{array}{l}1.461 \\
{[2.0596]}\end{array}$ & $\% * *$ \\
\hline$(-5,+5)$ & $\begin{array}{l}1.809 \\
{[4.6275]}\end{array}$ & $\% * * *$ & $\begin{array}{l}2.719 \\
{[3.1232]}\end{array}$ & $\% * * *$ & $\begin{array}{l}1.288 \\
{[3.6001]}\end{array}$ & $\% * * *$ & $\begin{array}{l}1.431 \\
{[1.8204]}\end{array}$ & $\% *$ \\
\hline
\end{tabular}

$*, * *, * * *$ denotes the significance of $\mathrm{t}$-stats at the $10 \%, 5 \%$ and $1 \%$, respectively.

To determine whether target type has an impact on acquirer wealth immediately after a takeover announcement Table 6 reports the effect of target type for all, single and multiple acquirer sample groups for private, public and subsidiary targets. The table also displays the difference in performance between single and multiple acquirers.

At first glance we can observe a noticeable difference between public and private/subsidiary target deals. Takeovers involving public firms results in non-statistically insignificant negative returns across all three sample groups and is consistent when testing for robustness. However takeovers of private and subsidiary target deals result in statistically significant abnormal returns for all three sample groups. This is also consistent when testing for robustness. These results are compatible with previous studies (see; Fuller et al., 2002; Moeller et al., 2003; Billet \& Qian, 2005; Ismail, 2008). Based on the figures in Table 6 the null hypothesis $H 5_{0 a}$ is rejected in favour of $H 5_{1 a}$ : acquirer shareholder returns is highly sensitive to target type.

Abnormal returns for acquirer shareholders appear to peak within the three days surrounding the announcement for private takeovers but continue to increase within the eleven days surrounding the announcement for subsidiary targets. Whilst takeovers of subsidiary and private firms start off with similar abnormal returns, $1.257 \%$ and $1.232 \%$ respectively for the event window $(-1,+1)$, subsidiary firm takeovers continue to yield an increase in abnormal return whilst private takeover deal returns decrease, $1.809 \%$ and $1.178 \%$ respectively for the event window $(-5,+5)$. This indicates subsidiary deals portray better outlooks than private deals over a longer period.

Consistent with Ismail (2008), single acquirers outperform multiple acquirers across all three target types. When comparing the significance of the difference, Ismail (2008) report a statistical difference for all three target types for the period of $(-2,+2)$ whereas this study only report a statistical difference for private and subsidiary firms at $0.675 \%$ and $1.461 \%$ respectively, but none for public targets. However, since this study reports abnormal returns for single and multiple acquirers for public firms it is acceptable that the difference will also be insignificant. Therefore the hypothesis $H 5_{1 b}$ is favoured over $\mathrm{H}_{0 b}$ : any difference in abnormal returns between shareholders of single and multiple acquirers is affected by target status.

\subsubsection{Acquirer Wealth Gain by Target Location}

This table presents the cumulative average abnormal returns by domestic and foreign targets and difference for all, single and multiple UK acquirers and the difference between the two for the selected event windows $(-1,+1)$; $(-2,+2) ;(-5,+5)$. The results were calculated using the market model with an estimation window of $(-210,-21)$. Cross border effect is the difference in CAAR between domestic and foreign deals

Table 7. Cumulative average abnormal returns (CAAR) for all, single and multiple acquirers by location

\begin{tabular}{|c|c|c|c|c|c|c|c|c|}
\hline \multirow[b]{2}{*}{ Location } & \multicolumn{2}{|c|}{ All } & \multicolumn{2}{|c|}{ Single acquirers } & \multicolumn{2}{|c|}{ Multiple acquirers } & \multicolumn{2}{|c|}{ Difference (single less multiple) } \\
\hline & \multicolumn{2}{|c|}{$\begin{array}{l}\text { CAAR } \\
\text { [t-stat] }\end{array}$} & \multicolumn{2}{|c|}{$\begin{array}{l}\text { CAAR } \\
\text { [t-stat] }\end{array}$} & \multicolumn{2}{|c|}{$\begin{array}{l}\text { CAAR } \\
\text { [t-stat] }\end{array}$} & \multicolumn{2}{|c|}{$\begin{array}{l}\text { CAAR } \\
\text { [t-stat] }\end{array}$} \\
\hline \multicolumn{9}{|c|}{ Panel A. Difference in performance between single and multiple acquirers } \\
\hline Domestic (No.\#) & \multicolumn{2}{|c|}{$(912)$} & $(341$ & & \multicolumn{2}{|c|}{ (571) } & & \\
\hline$(-1,+1)$ & $\begin{array}{c}1.149 \\
{[6.0986]}\end{array}$ & $\% * * *$ & $\begin{array}{c}1.609 \\
{[4.2256]}\end{array}$ & $\% * * *$ & $\begin{array}{c}0.875 \\
{[4.4492]}\end{array}$ & $\% * * *$ & $\begin{array}{c}0.734 \\
{[1.7130]}\end{array}$ & $\% *$ \\
\hline$(-2,+2)$ & $\begin{array}{c}1.350 \\
{[6.1905]}\end{array}$ & $\% * * *$ & $\begin{array}{c}1.691 \\
{[3.7979]}\end{array}$ & $\% * * *$ & $\begin{array}{c}1.147 \\
{[5.0959]}\end{array}$ & $\% * * *$ & $\begin{array}{c}0.544 \\
{[1.0903]}\end{array}$ & $\%$ \\
\hline$(-5,+5)$ & $\begin{array}{c}1.220 \\
{[4.3469]}\end{array}$ & $\%$ *** & $\begin{array}{c}1.308 \\
{[2.3583]}\end{array}$ & $\% * *$ & $\begin{array}{c}1.168 \\
{[3.8599]}\end{array}$ & $\% * * *$ & $\begin{array}{c}0.140 \\
{[0.2222]}\end{array}$ & $\%$ \\
\hline Foreign (No.\#) & $(58$ & & $(1$ & & $(386$ & & & \\
\hline$(-1,+1)$ & $\begin{array}{c}1.063 \\
{[4.4406]}\end{array}$ & $\% * * *$ & $\begin{array}{c}1.906 \\
{[3.4322]}\end{array}$ & $\% * * *$ & $\begin{array}{c}0.636 \\
{[2.8491]}\end{array}$ & $\% * * *$ & $\begin{array}{c}1.271 \\
{[2.1232]}\end{array}$ & $\% * *$ \\
\hline
\end{tabular}




\begin{tabular}{|c|c|c|c|c|c|c|c|c|}
\hline$(-2,+2)$ & $\begin{array}{c}1.173 \\
{[4.1377]}\end{array}$ & $\% * * *$ & $\begin{array}{c}2.075 \\
{[3.1610]}\end{array}$ & $\% * * *$ & $\begin{array}{c}0.715 \\
{[2.6943]}\end{array}$ & $\% * * *$ & $\begin{array}{c}1.360 \\
{[1.9209]}\end{array}$ & $\% *$ \\
\hline$(-5,+5)$ & $\begin{array}{c}1.301 \\
{[3.6198]}\end{array}$ & $\% * * *$ & $\begin{array}{c}2.067 \\
{[2.4642]}\end{array}$ & $\% * *$ & $\begin{array}{c}0.912 \\
{[2.7273]}\end{array}$ & $\% * * *$ & $\begin{array}{c}1.154 \\
{[1.2783]}\end{array}$ & $\%$ \\
\hline Panel B & reffect & & & & & & & \\
\hline$(-1,+1)$ & $\begin{array}{c}0.086 \\
{[0.2818]}\end{array}$ & $\%$ & $\begin{array}{c}-0.297 \\
{[-0.4415]}\end{array}$ & $\%$ & $\begin{array}{c}0.239 \\
{[0.8050]}\end{array}$ & $\%$ & & \\
\hline$(-2,+2)$ & $\begin{array}{c}0.177 \\
{[0.4956]}\end{array}$ & $\%$ & $\begin{array}{c}-0.384 \\
{[-0.4844]}\end{array}$ & $\%$ & $\begin{array}{c}0.432 \\
{[1.2413]}\end{array}$ & $\%$ & & \\
\hline$(-5,+5)$ & $\begin{array}{l}-0.081 \\
{[-0.1770]}\end{array}$ & $\%$ & $\begin{array}{c}-0.758 \\
{[-0.7541]}\end{array}$ & $\%$ & $\begin{array}{c}0.255 \\
{[0.5663]}\end{array}$ & $\%$ & & \\
\hline
\end{tabular}

$*, * *, * * *$ denotes the significance of t-stats at the $10 \%, 5 \%$ and $1 \%$, respectively.

Table 7 shows the effect of domestic and foreign target location for all, single and multiple acquirer sample groups. Panel A displays the difference in performance between single and multiple acquirers whilst panel B shows the cross-border effect. Domestic deals account for 61\% of all takeovers between 2002 and 2006 and this figure is similar when separating single and multiple deals (63\% and $60 \%$ respectively), suggesting acquirer materialism does influence choice of target location.

Looking at the 'all' sample group, domestic and foreign deals yield statistically significant abnormal returns at $1 \%$ level of significance and is robust for all, single and multiple sample groups across the three event windows. This suggests the market sees potential synergetic gains from the takeover immediately surrounding the announcement. Domestic slightly outperforms foreign deals for the 'all' sample group, similar to Conn et al. (2003). Similar results are reported for multiple acquirers which is expected considering multiple acquirers make up the majority of the acquisitions that had taken place. Unexpectedly, the results for single acquirer are different with foreign deals outperform domestic deals, similar to studies conducted by Feito Ruiz and Menedez-Requejo (2009). However the difference is not statistically significant for all three sample groups. Therefore the null hypothesis $H 6_{0 a}$ is accepted: acquirer shareholder return is not affected by target location.

For the three days surrounding the takeover announcements single acquirers outperformed multiple acquirers by $0.734 \%$ in domestic deals and by $1.271 \%$ in foreign deals, both at significant levels. Ismail (2008) also reports significant difference between single and multiple acquirers for both deal types. However, the results in this study are less conclusive for the five and eleven days surrounding the announcement day, thus the hypothesis $H \sigma_{0 b}$ is regarded as inconclusive. $H \sigma_{0 b}$ : any difference in abnormal returns between shareholders of single and multiple acquirers is not affected by target location.

\subsubsection{Acquirer Wealth Gain by Target Relatedness}

This table presents the cumulative average abnormal returns by related, unrelated and difference for all, single and multiple UK acquirers and the difference between the two for the selected event windows $(-1,+1) ;(-2,+2)$; $(-5,+5)$. The results were calculated using the market model with an estimation window of $(-210,-21)$. Industry is defined as macro industry from Thomson-One-Banker. Effect of relatedness is the difference between related and unrelated deals.

Table 8. Cumulative average abnormal returns (CAAR) for all, single and multiple acquirers by relatedness

\begin{tabular}{|c|c|c|c|c|c|c|c|c|}
\hline & \multicolumn{2}{|l|}{ All } & \multicolumn{2}{|c|}{ Single acquirers } & \multicolumn{2}{|c|}{ Multiple acquirers } & \multicolumn{2}{|c|}{ Difference (multiple less single) } \\
\hline $\begin{array}{l}\text { Payment } \\
\text { method }\end{array}$ & $\begin{array}{l}\text { CAAR } \\
\text { [t-stat] }\end{array}$ & & $\begin{array}{l}\text { CAAR } \\
\text { [t-stat] }\end{array}$ & & $\begin{array}{l}\text { CAAR } \\
\text { [t-stat] }\end{array}$ & & $\begin{array}{l}\text { CAAR } \\
\text { [t-stat] }\end{array}$ & \\
\hline \multicolumn{9}{|c|}{ Panel A. Difference in performance between single and multiple acquirers } \\
\hline Related (No.\#) & $(1020)$ & & $(375)$ & & $(645)$ & & & \\
\hline$(-1,+1)$ & $\begin{array}{l}1.001 \\
{[5.5521]}\end{array}$ & $\% * * *$ & $\begin{array}{l}1.524 \\
{[3.9860]}\end{array}$ & $\% * * *$ & $\begin{array}{l}0.697 \\
{[3.9213]}\end{array}$ & $\% * * *$ & $\begin{array}{l}0.827 \\
{[1.9616]}\end{array}$ & $\% *$ \\
\hline$(-2,+2)$ & $\begin{array}{l}1.206 \\
{[5.7546]}\end{array}$ & $\% * * *$ & $\begin{array}{l}1.567 \\
{[3.5814]}\end{array}$ & $\% * * *$ & $\begin{array}{l}0.996 \\
{[4.6922]}\end{array}$ & $\% * * *$ & $\begin{array}{l}0.571 \\
{[1.7745]}\end{array}$ & $\% *$ \\
\hline$(-5,+5)$ & $\begin{array}{l}1.181 \\
{[4.2983]}\end{array}$ & $\% * * *$ & $\begin{array}{l}1.343 \\
{[2.3304]}\end{array}$ & $\% * *$ & $\begin{array}{l}1.087 \\
{[3.9236]}\end{array}$ & $\% * * *$ & $\begin{array}{l}0.256 \\
{[0.4005]}\end{array}$ & $\%$ \\
\hline Unrelated (No.\#) & $(474)$ & & $(162)$ & & $(3$ & & & \\
\hline$(-1,+1)$ & $\begin{array}{l}1,363 \\
{[5.2570]}\end{array}$ & $\% * * *$ & $\begin{array}{l}2.165 \\
{[3.8953]}\end{array}$ & $\% * * *$ & $\begin{array}{l}0.946 \\
{[3.5610]}\end{array}$ & $\% * * *$ & $\begin{array}{l}1.218 \\
{[1.9779]}\end{array}$ & $\% * *$ \\
\hline
\end{tabular}




\begin{tabular}{|c|c|c|c|c|c|c|c|c|}
\hline$(-2,+2)$ & $\begin{array}{l}1.444 \\
{[4.7093]}\end{array}$ & $\% * * *$ & $\begin{array}{l}2.443 \\
{[3.5230]}\end{array}$ & $\% * * *$ & $\begin{array}{l}0.925 \\
{[3.1653]}\end{array}$ & $\% * * *$ & $\begin{array}{l}1.518 \\
{[2.0170]}\end{array}$ & $\% * *$ \\
\hline$(-5,+5)$ & $\begin{array}{l}1.403 \\
{[3.7963]}\end{array}$ & $\% * * *$ & $\begin{array}{l}2.144 \\
{[2.7419]}\end{array}$ & $\% * * *$ & $\begin{array}{l}1.018 \\
{[2.6305]}\end{array}$ & $\% * * *$ & $\begin{array}{l}1.126 \\
{[1.6903]}\end{array}$ & $\% *$ \\
\hline \multicolumn{9}{|c|}{ Panel B.Effect of relatedness } \\
\hline$(-1,+1)$ & $\begin{array}{l}-0.362 \\
{[-1.1453]}\end{array}$ & $\%$ & $\begin{array}{l}-0.641 \\
{[-0.9496]}\end{array}$ & $\%$ & $\begin{array}{l}-0.249 \\
{[-0.7800]}\end{array}$ & $\%$ & & \\
\hline$(-2,+2)$ & $\begin{array}{l}-0.238 \\
{[-0.6418]}\end{array}$ & $\%$ & $\begin{array}{l}-0.876 \\
{[-1.0688]}\end{array}$ & $\%$ & $\begin{array}{l}0.070 \\
{[0.1951]}\end{array}$ & $\%$ & & \\
\hline$(-5,+5)$ & $\begin{array}{l}-0.222 \\
{[-0.4816]}\end{array}$ & $\%$ & $\begin{array}{l}-0.801 \\
{[-0.8244]}\end{array}$ & $\%$ & $\begin{array}{l}0.069 \\
{[0.1445]}\end{array}$ & $\%$ & & \\
\hline
\end{tabular}

$*, * *, * * *$ denotes the significance of $\mathrm{t}$-stats at the $10 \%, 5 \%$ and $1 \%$, respectively.

Table 8 reports the effect of target relatedness for all, single and multiple acquirer sample groups. Panel A displays the difference in performance between single and multiple acquirers whilst panel B shows the cross-border effect. There were 1020 related takeover and only 474 unrelated takeovers between 2002 and 2006. This figure suggests management pursue operational synergies from related deals more often than the financial synergies from a diversified portfolio. This is despite the fact that unrelated deals generally performed better than related deals for the sample groups (Ismail, 2008).

When considering the event window $(-2,+2)$, related deals in the 'all' sample group obtain $1.206 \%$ CAAR and unrelated deals is slightly higher at $1.444 \%$. Single acquirers in this event window experience higher CAARs at $1.567 \%$ and $2.443 \%$ for related and unrelated deals respectively, whilst multiple acquirers experience lower CAARs at $0.996 \%$ and $0.935 \%$, respectively, at $1 \%$ level of significance. These figures correspond to Morck et al. (1990) who also found unrelated takeovers perform better than related takeovers and contradicts the findings of Walker (2000). However, the differences between related and unrelated deals across the three sample groups do not appear statistically significant and thus the null hypothesis $H 7_{O a}$ is accepted: acquirer shareholder return is not affected by target relatedness.

Like all the previous deal characteristics, single acquirers outperform multiple acquirers in both related and unrelated deals. Crucial, the difference is significant across all samples with the exception of related deals for the event window $(-5,+5)$. Ismail (2008) also found similar results. Taking this into consideration, it can be argued that the null hypothesis $H 7_{0 b}$ is rejected in favour of the alternative $H 7_{l b}$ : any difference in abnormal returns between shareholders of single and multiple acquirers is affected by target relatedness.

\section{Summary and Conclusion}

\subsection{Conclusion}

Findings suggest that acquirer shareholders as a group experience significant gains during the immediate days surrounding the announcement event and the overall short-term event window. The results also rule out any significant informational leakage that would otherwise affect the CAARs. Crucially, higher CAARs are gained by single acquirers and this is consistent under different deal characteristics, supporting previous findings by Ismail (2008). The difference is most significant for target status but also for method of payment and relatedness. The difference is not significant for target location.

Patterns for sequential acquisitions are deduced to determine what effect deal order number and first time successful/unsuccessful acquisitions has on multiple acquirers shareholders' wealth. CAARs for sequential acquisitions follow a declining pattern but remain significantly positive up to the sixth deal, a finding that supports diminishing hypothesis. The study indicates experience does not automatically suggest acquirers are likely to observe higher significant gains. On the contrary, single acquirers on average generate higher CAARs, but the risk is that unsuccessful single acquirers losses are greater than unsuccessful multiple acquirers. This suggests highly risk adverse investors should avoid investing in single acquiring firms.. However unlike most research, this study also found learning hypothesis can be experienced subsequent to hubris hypothesis, that is, hubris is not permanent.

Additional research questions were put forth to analyse whether any significant difference could be found within deal characteristics, i.e. effect of relatedness, which is the performance difference between related and unrelated deals. In contrast to previous evidence, the results indicate acquirers, all, single and multiple, generate higher CAARs when the mode of payment is equity rather than cash offering for private and subsidiary target firms. On the other side, significant losses are observed for equity deals for public firms whilst cash deals yield negligible losses. These results are robust for the three, five and ten days surrounding the announcement days. However for 
larger event windows it is found that cash deals do in fact outperform equity deals and support previous evidence. This highlights the sensitivity of testing for deal characteristics over a constrained event window sample. Significant differences in related and unrelated, cash and equity, domestic and foreign deals could not be identified using short event-windows.

\subsection{Research Limitations and Proposal for Further Research}

There are a number of limitations and constraints which may or may not have material impact on the research output of this study. First, the data sample was limited to completed deals. Although this is common in other research (Fuller et al., 2002; Ismail, 2008) the impact of unsuccessful bids for multiple acquirers may impact any sequential takeover bids. This could be tested in future research.

Second, the data sample of this study is limited to the five years between 2002 and 2006. The author found many sequences began before or continued after this sample period and a large number of deal order required adjustments. To avoid this issue future research should consider a larger data range similar to Ismail (2008). Higson and Elliot (1998) found that by dividing samples into time periods led to considerable differences in results so any research over a longer period should be tested for sensitivity over time periods.

Third, to prevent sequential acquisitions affecting abnormal returns this study maintains an exclusion zone of twelve days, that is when two acquisitions by the same firm are within twelve days of each other they are excluded. This method limits the event windows that could be tested to $(-1,+1) ;(-2,+2)$; and $(-5+5)$. However, in order to test for deal characteristics a longer event window is required. This is particularly evident for payment method (see Table 5a, 5b).Therefore, it is recommended that the effect of longer event windows should be investigated, with and without exclusions zones for sensitivity purposes.

Sensitivity tests examining the effect of multiple acquisition definition are also carried out. In these tests the designation of a multiple acquirer was based on post-acquisition event, thus first acquisitions of a sequence were categorised as multiple acquirers. These tests display different results, in particular there is evidence of marginal significant difference between single and multiple acquirers. The findings highlight the sensitivity of the results on the definition of parameters such as a 'multiple' acquirer. A suggestion for further research is that different definitions of multiple acquirer, hiatus periods and exclusions zones should be tested.

Finally, note that existing empirical literature on single versus multiple acquirers' takeover announcement performance is limited compared to the general impact of takeover announcement literature. Therefore further research in this area could be beneficial considering the large number and value of M\&As globally.

\section{References}

Aktas, N., De Bodt, E., \& Roll, R. (2005). Hubris, Learning, and M\&A Decisions. Finance, Anderson Graduate School of Management. UC Los Angeles.

Aktas, N., De Bodt, E., \& Roll, R. (2007). Learning, hubris and corporate serial acquisitions. Working Paper, UC Los Angeles. https://doi.org/10.2139/ssrn.721882

Antoniou, A., Arbour, P., \& Zhao, H. (2008). How much is too much: are merger premiums too high? European Financial Management, 14(2), 268-87. https://doi.org/10.1111/j.1468-036X.2007.00404.x

Archbold, S. (2000). A re-examination of management motives: in related and unrelated acquisitions. Economic Issues, 5(3), 63-87.

Ardalan, K. (2008). On the role of paradigm in finance. Ashgate Publishing Ltd, Hampshire.

Arnold, G. (2008). Corporate Financial Management (4th ed.). Pearson Education Limited, Essex

Asquith, P. (1983). Merger bids, uncertainty and stockholder returns. Journal of Financial Economics, 11, 51-83. https://doi.org/10.1016/0304-405X(83)90005-3

Baker, R. D., \& Limmack, R. J. (2001). UK takeovers and acquiring company wealth changes: The impact of survivorship and other potential selection biases on post-outcome performance. Working Papers, University of Stirling Accounting, Finance \& Law. https://doi.org/10.2139/ssrn.268633

Ball, R., \& Brown, P. (1968). An empirical evaluation of accounting income numbers. Journal of Accounting Research, 6(2), 159-78. https://doi.org/10.2307/2490232

Berkovitch, N. (1993). Motives for takeovers: An empirical investigation. Journal of Financial and Quantitative Analysis, 28(3), 374-62. https://doi.org/10.2307/2331418

Billet, M. T., \& Qian, Y. (2005). Are overconfident managers born or made? Evidence of self-attribution bias from frequent acquirers. Working Paper, Tipple College of Business, University of Iowa. 
https://doi.org/10.2139/ssrn.687534

Black, B. S. (2000). The first international merger wave (and the fifth and last U.S. wave). University of Miami Law Review, 54, 799-818. https://doi.org/10.2139/ssrn.231101

Bouman, C., Fuller, K., \& Nain, A. (2002). The performance of stock-price driven acquisitions. Working Papers, Concordia University.

Brealey, R., \& Myers, S. C. (2010). Principles of Corporate Finance, Global Edition.

Brown, S. J., \& Warner, J. B. (1980). Measuring security price performance. Journal of Financial Enonomics, 8 , 205-58. https://doi.org/10.1016/0304-405X(80)90002-1

Cakici, N., Hessel, C., \& Tandon, K. (1991). Foreign Acquisitions in the United States and the Effect on Shareholder Wealth. Journal of International Financial Managementand Accounting, 3(1), 39-60. https://doi.org/10.1111/j.1467-646X.1991.tb00090.x

Cartwright, S., \& Cooper, C. L. (2010). Managing Mergers Acquisitions \& Strategic Alliances. Integrating People and Cultures (2nd ed., pp. 20-32). Lightning Source UK Ltd, Milton Keynes.

Chang, S. (1998). Takeovers of privately held target, method of payment, and bidder returns. Journal of Finance, 53(2), 773-84. https://doi.org/10.1111/0022-1082.315138

Chang, S., \& Mais, E. (2000). Managerial motives and merger financing. The Financial Review, 35, 139-52. https://doi.org/10.1111/j.1540-6288.2000.tb01434.x

Collis, J., \& Hussey, R. (2009). Business Research: A practical guide for undergraduate and postgraduate students (3rd ed.). Palgrave MacMillan ltd, Hampshire.

Conn, R. C. L., Cosh, A., Guest, P. M., \& Hughes, A. (2003). The impact of UK acquirers of domestic, cross-border, public and private acquisition. Working Paper, University of Cambridge, Iss. 276.

Conn, R. C. L., Cosh, A., Guest, P. M., \& Hughes, A. (2004). Why must all good things come to an end? The performance of multiple acquirers. Working Paper, University of Cambridge. https://doi.org/10.2139/ssrn.499310

DePamphilis, D. M. (2009). Mergers Acquisitions, and other restructuring activities (5th ed.). London: Academic Press Publication.

Dickerson, A., Gibson, H., \& Tsakalotos, E. (1997). The impact of acquisitions on company performance, Evidence from a large panel of UK firms. Oxford Economic Papers, 49, 344-61. https://doi.org/10.1093/oxfordjournals.oep.a028613

Fama, E. F., Fisher, L., Jensen, M. C., \& Roll, R. (1969). The adjustment of stock prices to new information. International Economic Review, 10(1), 1-21. https://doi.org/10.2307/2525569

Feito-Ruiz, I., \& Menendez-Requejo, S. (2009). Cross-border mergers and acquisitions in different legal environments. University of Oviedo, June, 24-7. Retrieved from http://www.efmaefm.org/OEFMAMEETINGS/EFMA\%20ANNUAL\%20MEETINGS/2009-milan/345.pdf

Firth, M. (1976). Share prices and Mergers. Westmead, Farnborough: Lexington Books.

Firth, M. (1979). The profitability of takeovers and mergers. The Economic Journal, 89(354), 316-28. https://doi.org/10.2307/2231604

Firth, M. (1980). Takeovers, shareholder return, and the theory of the firm. Journal of Economics, 84(2), 235-60. https://doi.org/10.2307/1884539

Floegel, V., Gebken, T., \& Johanning, L. (2005). The Dynamics Within Merger Waves: Evidence from Industry Merger Waves. SSRN Working Paper No. 669525, European Business School, Oestrich-Winkel. https://doi.org/10.2139/ssrn.669525

Franks, J. R., Broyles, J. E., \& Hecht, M. (1977). An industry study of the profitability of mergers in the UK. Journal of Finance, 32, 1513-25. https://doi.org/10.1111/j.1540-6261.1977.tb03351.x

Franks, J., \& Harris, R. (1989). Shareholder Wealth Effects of Corporate Takeovers - The UK Experience 1955-1985. Journal of Financial Economics, 23, 225-249. https://doi.org/10.1016/0304-405X(89)90057-3

Fuller, K., Netter, J., \& Stegemoller, M. (2002). What do returns to acquiring firms tell us? Evidence from firms that make many acquisitions. Journal of Finance, 57, 1763-94. https://doi.org/10.1111/1540-6261.00477

Gebken, T. (2008). The Dynamics within merger waves: evidence from the industry merger waves of the 1990s. 
Doctoral Thesis/Dissertation.

Gorton, G., Kahl, M., \& Rosen, R. J. (2009). Eat or ne eaten: a theory of mergers and firm size. The Journal of Finance, 64, 1291. https://doi.org/10.1111/j.1540-6261.2009.01465.x

Gregory, A., \& Matatko, J. (2005). Long run abnormal returns to acquiring firms. University of Exeter, 5(2).

Healy, P. M., Palepu, K. G., \& Ruback, R. (1992). Does corporate performance improve after mergers? Journal of Financial Economics, 31, 135-75. https://doi.org/10.1016/0304-405X(92)90002-F

Healy, P. M., Palepu, K. G., \& Ruback, R. (1997). Which takeovers are profitable? Strategic or financial? Sloan Management Review, 45-57.

Higson, C., \& Elliot, J. (1998). Post-takeover returns: The UK evidence. Journal of Empirical Finance, 5, 27-46. https://doi.org/10.1016/S0927-5398(96)00015-1

Hodgkinson, L., \& Partington, G. H. (2008). The motivation for takeovers in the UK. Journal of Business Finance \& Accounting, 35, 102-26. https://doi.org/10.1111/j.1468-5957.2007.02063.X

Hovers, J. (1973). Expansion Through Acquisitions. London: Business Books Ltd.

Ismail, A. (2008). Which acquirer gain more, single or multiple? Recent evidence from the USA market. Global Finance Journal, 19, 72-84. https://doi.org/10.1016/j.gfj.2008.01.002

Jensen, M., \& Meckling, W. H. (1976). Theory of the firm: Managerial behaviour, agency costs and ownership structure. Journal of Financial Economics, 3, 305-60. https://doi.org/10.1016/0304-405X(76)90026-X

Limmack. (1991). Corporate mergers and shareholder wealth effects: 1977-198. Accounting and Business Research, 21(83), 239-51. https://doi.org/10.1080/00014788.1991.9729838

Lipton, M. (2006). Merger Waves in the $19^{\text {th }}, 20^{\text {th }}$ and $21^{\text {st }}$ centuries. The Davies Lecture, Osgoode Hall Law School, York University, September 14.

Loderer, C., \& Martin, K. (1990). Corporate acquisitions by listed firms: The experience of a comprehensive sample. Financial Management, 17-33. https://doi.org/10.2307/3665607

Loughran, T., \& Vijh, A. M. (1997). Do long term shareholders benefit from corporate acquisitions? The Journal of Finance, 52(5), 1765. https://doi.org/10.1111/j.1540-6261.1997.tb02741.x

MacKinlay. (1997). Event Studies in Economics and Finance. Journal of Economic Literature, 35(1), 13-39.

Malatesta, P. H., \& Thompson, R. (1985). Partially anticipated events: A model of stock price reactions with application to corporateacquisitions. Journal of Financial Economics, 14, 237-250. https://doi.org/10.1016/0304-405X(85)90016-9

Malmendier, U., \& Tate, G. A. (2008). Who makes acquisitions? CEO overconfidence and the market's reaction. Journal of Financial Economics, 89, 20-43. https://doi.org/10.1016/j.jfineco.2007.07.002

Mcwilliam, A., \& Siegel, D. (1997). Event studies in management research: Theoretical and empirical issues. Academy of Management Journal, 40(3). https://doi.org/10.2307/257056

Meeks, G. (1977). Disappointing Marriage: A Study of the Gains from Merger. London: Cambridge University Press.

Megginson, W. L. (2005) 'Introduction to corporate finance (1st ed.). South-Western, London.

Moeller, S., Schlingemann, F., \& Stulz, R. (2003). Wealth destruction on a massive scale? A study of acquiring-firm returns in the recent merger wave. Journal of Finance, 75, 757-82.

Moeller, S., Schlingemann, F., \& Stulz, R. (2004). Firm size and the gains from acquisitions. Journal of Financial Economics, 73, 201-28. https://doi.org/10.1016/j.jfineco.2003.07.002

Mork, R. A., Sliefer, A., \& Vishny, R. W. (1990). Do managerial objectives drive bad acquisitions? Journal of Finance, 43, 31-48. https://doi.org/10.1111/j.1540-6261.1990.tb05079.x

Mukherjee, T. K., Kiymaz, H., \& Baker, H. K. (2004, Winter). Merger Motives and Target Valuation: A Survey Evidence from CFOs. Journal of Applied Finance, 14(2).

Myers, S. C., \& Majiluf, N. (1984). Corporate financing and investment decisions when firms have information that investors do not have. Journal of Financial Economics, 13, 187-221. https://doi.org/10.1016/0304-405X(84)90023-0

Napier, N. K. (1989). Mergers and Acquisitions: Human resource issues and outcomes. A review and suggested 
typology. Journal of Management Studies, 26 May. https://doi.org/10.1111/j.1467-6486.1989.tb00728.x

Noe, R. (2002). Mergers and Acquisitions. MHR 860, Ohio State University Fisher College Business, Jan 17.

Patell, J. M. (1976). Corporate forecast of earnings per share and stock price behaviour: Empirical tests. Journal of Accounting Research, 14(2), 246-74. https://doi.org/10.2307/2490543

Ravenscraft, D. J., \& Scherer, F. M. (1987). Mergers, Sell-Offs and Economic Efficiency. International Journal of Industrial Organisation, 6(3), 401-5.

Roll, R. (1986, April). The hubris hypothesis of corporate takeovers. Journal of Business, 59(2), 197-216. https://doi.org/10.1086/296325

Rovit, S., \& Lemire, C. (2003). Your best M\&A strategy: Smart deal makers methodically acquire through good times and bad. Harvard Business Review. Retrieved from http://hbr.org/2003/03/your-best-ma-strategy/ar/1

Schipper, K., \& Thompson, R. (1983). Evidence on the capitalized value of merger activity for acquiring firms. Journal of Financial Economics, April, 85-119. https://doi.org/10.1016/0304-405X(83)90006-5

Smith, M. (2003). Research Methods in Accounting. London: Sage Publishing Ltd. https://doi.org/10.4135/9781849209809

Sprecher, C. R., \& Perti, M. A. (2005). Large losses, risk management and stock price. The Journal of Risk and Insurance, 50(1), 107-17. https://doi.org/10.2307/252419

Sudarsanam, S., \& Mahate, A. A. (2003). Glamour acquirers, method of payment \& post-acquisitions performance: The UK evidence. Journal of Business Finance \& Accounting, 30(1-2), 299-342. https://doi.org/10.1111/1468-5957.00494

Sudarsanam, S., \& Mahate, A. A. (2006). Are friendly acquisitions too bad for shareholders and managers? British Journal of Management, 17(5-6), 57.

Sudarsanam, S., Holl, P., \& Salami, A. (1996). Shareholder wealth gains in mergers: Effect of synergy and ownership structure.Journal of Business Finance \& Accounting, 23(5-6), 673-98. https://doi.org/10.1111/j.1468-5957.1996.tb01148.x

UNCTAD (United Nations Conference on Trade and Development) (2000). World Investment Report 2000. New York and Geneva: United Nations publication.

Walker, M. (2000) Corporate takeovers, strategic objective and acquiring firm shareholder wealth. Financial Management, 20, 55-66. https://doi.org/10.2307/3666361

Weston, J. F., Mitchell, M. L., \& Mulherin, J. H. (2004). Takeovers restructuring, and corporate governance (4th ed.). Prentice Hall.

\section{Notes}

Note 1. Market stock data is only available between Monday and Friday, thus appropriate adjustments are made.

Note 2. Although testing UK data, Datastream information is collected in USD.

\section{Appendix}

Figure A1. Abnormal returns to acquirer and target shareholders around announcement period

\begin{tabular}{|c|c|c|c|c|c|}
\hline \multirow[t]{2}{*}{ UK Studies } & \multirow[t]{2}{*}{ Event Window } & \multicolumn{2}{|c|}{ Sample } & \multicolumn{2}{|c|}{ Abnormal Returns } \\
\hline & & Period & number & Target $\%$ & Bidder $\%$ \\
\hline Sudarsanam, Mahate (2003) & -1 day to +1 day & 1983-1995 & 519 & - & -1.39 to -1.47 \\
\hline Antoniou et al (2008) & -2 days to +2 days & $1985-2004$ & 396 & 17 & -1.4 \\
\hline Firth (1980) & 1 month & $1969-1975$ & 563 & 28 & -6 \\
\hline Franks and Harris (1989) & 1 month & $1955-1985$ & 1898 & 23 & 1 \\
\hline Franks and Harris (1989) & -4 months to +1 month & $1955-1985$ & 1898 & 30 & 7.9 \\
\hline Franks et al (1977) & -4 months to +1 month & $1955-1972$ & 94 & 26 & 0.1 \\
\hline Sudarsanam et al (1996) & -20 to +40 days & $1980-1990$ & 429 & 29 & -4 \\
\hline Higson and Elliott (1998) & Bidding Period & $1975-1990$ & 830 & 38 & -0.4 \\
\hline Archbold (2000) & Bidding period & 1980-1995 & 522 & 19 & -3 \\
\hline Hodgkinson and Partington (2008) & -300 days to +5 days & 1984-1998 & 208 & 27 & 0.03 \\
\hline Sudarsanam, Mahate (2003) & From announcement date to +3 year completion & 1983-1995 & 519 & - & -15 \\
\hline
\end{tabular}

Note. This table illustrates the results of the studies discussed in section 2.1 regarding the impact of M\&A announcement on shareholders' wealth for successful bids. A breakdown of the event windows is given based on descending order from smallest to largest. 
Figure A2. Comparative sample statistics for all, single and multiple acquirers across different deal characteristics

\begin{tabular}{|c|c|c|c|c|c|c|c|c|c|}
\hline & \multicolumn{3}{|c|}{ All } & \multicolumn{3}{|c|}{ Multiple acquirers } & \multicolumn{3}{|c|}{ Single acquirers (first of a sequence) } \\
\hline & N\# & $\begin{array}{c}\text { Deal value } \\
(\$ \mathrm{~m})\end{array}$ & $\begin{array}{c}\text { Acquirer size } \\
(\$ \mathrm{~m})\end{array}$ & N\# & $\begin{array}{c}\text { Deal value } \\
(\$ \mathrm{~m})\end{array}$ & $\begin{array}{c}\text { Acquirer size } \\
(\$ \mathrm{~m})\end{array}$ & N\# & $\begin{array}{c}\text { Deal value } \\
(\$ \mathrm{~m})\end{array}$ & $\begin{array}{c}\text { Acquirer size } \\
(\$ \mathrm{~m})\end{array}$ \\
\hline Full Sample & 1494 & 103 & 1951 & 957 & 120 & 2492 & 537 & 89 & 986 \\
\hline \multicolumn{10}{|c|}{ Target public status } \\
\hline Private & 904 & 48 & 1037 & 581 & 55 & 1164 & 323 & 33 & 813 \\
\hline Pubic & 96 & 492 & 8465 & 62 & 587 & 11911 & 34 & 345 & 2180 \\
\hline Subsidiary & 494 & 128 & 2354 & 314 & 152 & 3089 & 180 & 86 & 1070 \\
\hline \multicolumn{10}{|c|}{ Payment method } \\
\hline Cash & 844 & 108 & 2608 & 561 & 120 & 3109 & 282 & 83 & 1612 \\
\hline Equity & 352 & 79 & 335 & 199 & 100 & 499 & 155 & 52 & 126 \\
\hline Others & $598^{1}$ & & & & & & & & \\
\hline \multicolumn{10}{|c|}{ Target location } \\
\hline Domestic & 912 & 78 & 941 & 571 & 86 & 1189 & 341 & 64 & 526 \\
\hline Foreign & 582 & 141 & 3532 & 386 & 171 & 4419 & 196 & 83 & 1787 \\
\hline \multicolumn{10}{|l|}{ Relatedness } \\
\hline Unrelated & 474 & 60 & 1469 & 675 & 149 & 2848 & 375 & 77 & 844 \\
\hline Related & 1020 & 122 & 2175 & 312 & 62 & 1549 & 162 & 57 & 1316 \\
\hline
\end{tabular}

Note. This table presents a statistical summary for the whole sample, single and multiple UK acquirers. Takeover announcement are between January $1^{\text {st }} 2002$ and December $31^{\text {st }} 2006$, as reported by Thompson-One-Banker, excluding financial institutions, uncompleted and unsuccessful bids; where the deal value is at least one million USD and the acquirers gain control of a public, private or subsidiary target firm. The table is distributed across four levels: target public status of private, public or subsidiary; method of payment is either cash or equity; location of target firm is either domestic (UK) or cross-border (non-UK); relatedness of the deal is either related or unrelated depending on whether the target is from the same macro-industry as defined by Thomson-One-Banker. Deal value is the average value paid per acquisition. Acquirer size is taken as the mean average market value of the firms' equity two months prior to the acquisition announcement.

Figure A3. Cumulative abnormal returns (CAR) and Cumulative average abnormal returns (CAAR) for successful first merger deals and subsequent deal

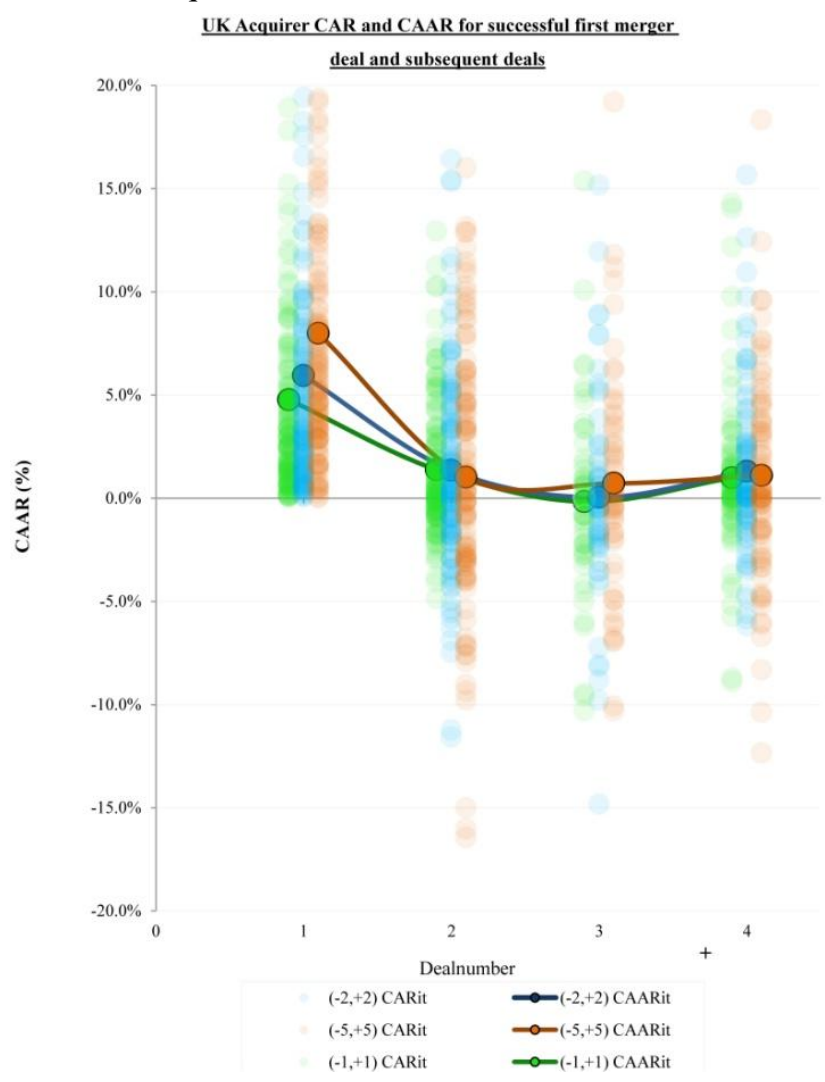

Note. This graph presents a graphical illustration of the cumulative abnormal returns (CAR) and cumulative average abnormal returns (CAAR) for successful first merger deals and subsequent deals. The first three deals of a sequence are recorded in individual sub-sample groups, with fourth onwards in a fourth sub-sample group. 
Figure A4 Cumulative abnormal returns (CAR) and Cumulative average abnormal returns (CAAR) for unsuccessful first merger deals and subsequent deals

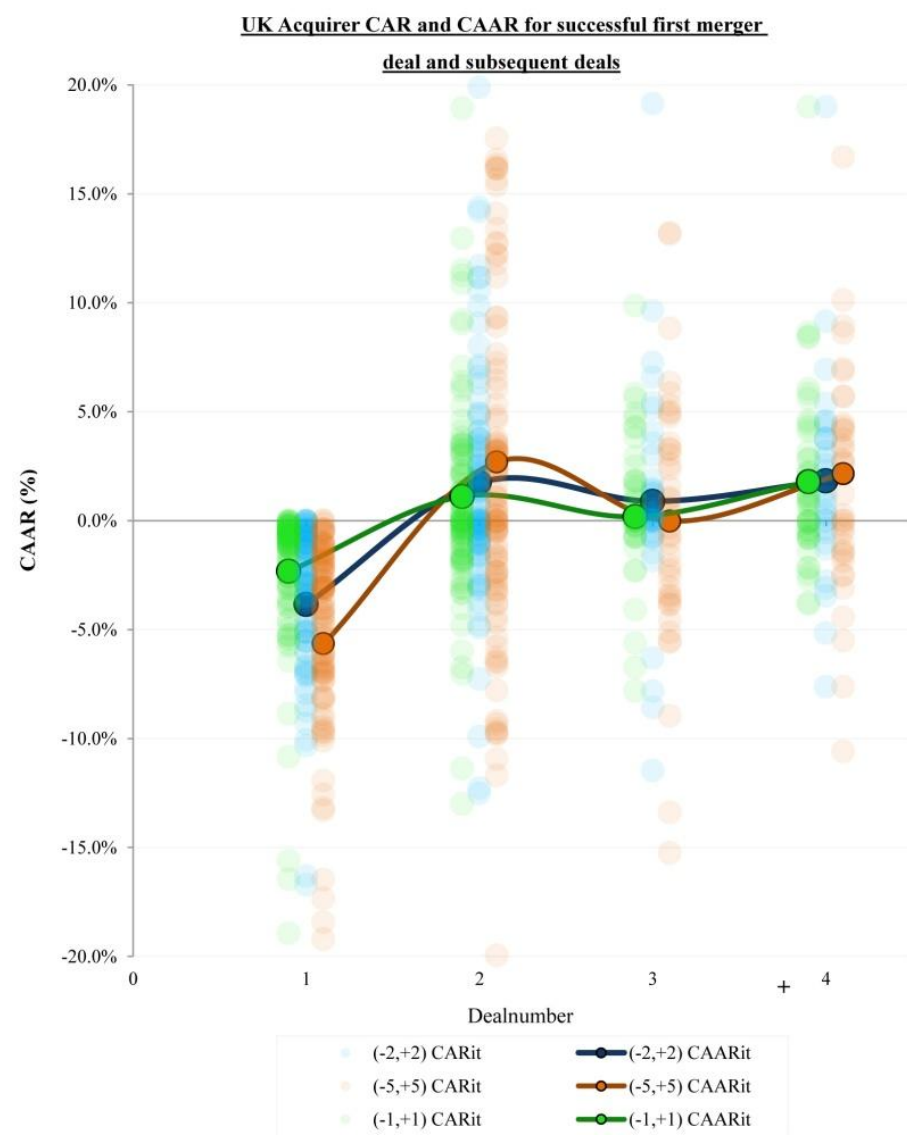

Note. This graph presents a graphical illustration of the cumulative abnormal returns (CAR) and cumulative average abnormal returns (CAAR) for unsuccessful first merger deals and subsequent deals. The first three deals of a sequence are recorded in individual sub-sample groups, with fourth onwards in a fourth sub-sample group.

\section{Copyrights}

Copyright for this article is retained by the author(s), with first publication rights granted to the journal.

This is an open-access article distributed under the terms and conditions of the Creative Commons Attribution license (http://creativecommons.org/licenses/by/4.0/). 